\title{
The Impact of Fleet Size, Harvesting Site Reserve, and Timing of Machine Relocations on the Performance Indicators of Mechanized CTL Harvesting in Finland
}

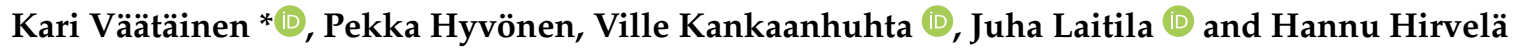 \\ Natural Resources Institute Finland (Luke), Latokartanonkaari 9, 00790 Helsinki, Finland; \\ pekka.hyvonen@luke.fi (P.H.); ville.kankaanhuhta@luke.fi (V.K.); juha.laitila@luke.fi (J.L.); \\ hannu.hirvela@luke.fi (H.H.) \\ * Correspondence: kari.vaatainen@luke.fi; Tel.: +358-29-391-3259
}

check for updates

Citation: Väätäinen, K.; Hyvönen, P.; Kankaanhuhta, V.; Laitila, J.; Hirvelä, $\mathrm{H}$. The Impact of Fleet Size,

Harvesting Site Reserve, and Timing of Machine Relocations on the Performance Indicators of Mechanized CTL Harvesting in Finland. Forests 2021, 12, 1328. https://doi.org/10.3390/f12101328

Academic Editor: Gianni Picchi

Received: 30 August 2021

Accepted: 24 September 2021

Published: 28 September 2021

Publisher's Note: MDPI stays neutral with regard to jurisdictional claims in published maps and institutional affiliations.

Copyright: (c) 2021 by the authors. Licensee MDPI, Basel, Switzerland. This article is an open access article distributed under the terms and conditions of the Creative Commons Attribution (CC BY) license (https:// creativecommons.org/licenses/by/ $4.0 /)$.
Abstract: Upscaling an operation typically results in economies of scale, i.e., cost advantages in business, especially when the production unit's utilization rate can be improved. According to economic studies of mechanized timber harvesting, large wood harvesting entrepreneurs tend to be more successful in business than small entrepreneurs. What are the factors that influence harvesting costs, and how great is their effect on costs? These questions were investigated in mechanized cut-to-length timber harvesting in Eastern Finland by varying (a) the size of the harvesting fleet, (b) the harvesting site reserve, and (c) the timing and duration of the working day of machine relocations, in the case of an entrepreneur using a discrete-event simulation method. Prior to the simulations, harvesting site data were generated from the National Forest Inventory data by the MELA software, and the spatial data analyses by ArcGIS. According to the results, largely because of the low utilization rate of the contractor's own relocation truck, the harvesting cost of a 2-harvestingunit (2 HU) scenario was $9 \%$ or $6 \%$ higher than $4 \mathrm{HU}$, and $13 \%$ or $8 \%$ higher than $8 \mathrm{HU}$, with or without a specifically employed driver of a relocation truck, respectively (the harvesting unit consists of a harvester and a forwarder). In the 4 and $8 \mathrm{HU}$ scenarios, harvesting costs decreased on average by $1 \%(0.3-1.5)$, when doubling the size of the harvesting site reserve. With fleet sizes of 6 and $8 \mathrm{HU}$, good utilization of a relocation truck reduced relocation costs, whereas machine costs only increased a small amount because of a longer machine relocation waiting time than with smaller entrepreneurs. The study raised the importance of entrepreneur-specific planning of machine relocations in the cost-efficient timber harvesting in Finland.

Keywords: CTL harvesting; harvesting fleet; discrete event simulation; machine relocation; harvesting cost; operation logistics; system analysis; economies of scale

\section{Introduction}

In Finland, roundwood harvesting is fully mechanized (99.98\% of annual cuttings) [1], and harvesting is carried out by cut-to-length (CTL) forest machines, i.e., by a harvester and a forwarder. In 2015-2020, the annual domestic harvesting of roundwood (industrial wood and energy wood) was 65.2-78.2 million $\mathrm{m}^{3}$ [2]. In recent years in Finland, a total of nearly 2000 harvesters have actively operated, with a roughly equal number of forwarders $[1,3]$. The machines are owned by private wood-harvesting entrepreneurs, who are responsible for the forest industry's domestic wood supply. The median fleet size of a forest machine entrepreneur in Finland is 2-3 forest machines (harvesters and/or forwarders), and most of the small entrepreneurs are subcontractors of larger wood-harvesting companies [4]. The shift to larger wood-harvesting entrepreneurs and the increased networking of smaller entrepreneurs with increased responsibilities and a versatile service provision have been seen as the most distinctive changes in the Finnish wood-harvesting business [5]. 
In Finland, the majority of wood harvesting entrepreneurs own a relocation truck, typically a 4-axle or 5-axle load-carrying truck with a low bed for the relocation of the entrepreneur's own machines. Alternative vehicles for machine relocations are low-bed trailers with a farm tractor or a truck as a prime mover. Relocation costs, the timing structure of work elements, operating scale, and/or relocation practices in machine relocations have been studied in Finland, e.g., by Kuitto et al. [6], Väätäinen et al. [7], Kärhä et al. [8], Friman [9], and Kauppinen [10]. According to the results, the typical relocation distance between harvesting sites is $25-30 \mathrm{~km}$, the duration of the relocation cycle for the truck is $2-2.5 \mathrm{~h}$, and the annual amount of driving in hours and kilometers for the relocation truck is 350-600 and 15,000-30,000 respectively. In a follow-up study of harwarders (a harvesting machine that cuts and processes trees and forwards them to the landing) by Kärhä et al. [11], the share of machine relocation was $2.5 \%$ of the total working time of the harwarder. The respective shares were $1.4-1.5 \%$ for harvesters and $0.9-1.1 \%$ for forwarders of the total machine computer time in a Swedish follow-up study by Eriksson and Lindroos [12]. According to studies by Friman [9], Kauppinen [10], and Jylhä et al. [4], the majority of machine relocations by truck were carried out by the entrepreneurs themselves, and the remaining relocations were undertaken either by forest machine operators, retired relatives, or the entrepreneur's other employed personnel. According to Jylhä et al. [4], personnel were specifically recruited to work with machine relocations, maintenance, and other supporting tasks in some companies with a large turnover (more than EUR 2 million/year).

Despite the low annual usage of relocation trucks and the consequent relatively high capital/fixed costs per harvested $\mathrm{m}^{3}$, even small entrepreneurs with 2 to 3 harvesterforwarder units tend to own a truck for the relocations instead of outsourcing them to relocation services. Entrepreneurs argue that this is mainly due to the need to control one's own relocations, maximizing the efficient operating time for harvesting, and ensuring flexibility in operations and planning $[7,9,10]$. In terms of efficient relocations, larger entities or clusters of harvesting sites near each other while operating, larger site reserves, optimized relocation truck routing, and sharing the free capacity of relocation trucks have been noted as means of decreasing the relocation costs and increasing machine utilization (MU\%) of harvesting machines, e.g., [7,9,12].

The profitability of the wood-harvesting business has remained low in Sweden and Finland [4,5,13-17]. Large wood-harvesting entrepreneurs tend to be more successful than small entrepreneurs $[4,5,15,17]$. For example, the existence of a business agreement and negotiation skills in tendering, networking with other enterprises, management and leadership skills, the versatility of services provided, the rate of skilled and productive operators, the use of incentive payment systems, and efficient operations and their scale (e.g., production capacity, $\mathrm{MU} \%$, operations efficiency) have been assessed to have an impact on profitability $[4,12,14,15]$.

Productivity and cost assessment-based system analyses of mechanized CTL harvesting operations for industrial roundwood have been conducted by both static/deterministic methods, e.g., $[11,18,19]$ and dynamic analysis methods using discrete-event simulation (DES) e.g., [12,20-25]. Machine relocations in roundwood harvesting have been included in system analysis modeling in studies of, e.g., $[12,23,25,26]$. In the Nordic countries, extensive productivity studies for CTL harvesters and forwarders in the current millennium have been conducted by Nurminen et al. [27] and Eriksson and Lindroos [28], and separately for harvesters by Liski et al. [29]. Follow-up studies of machine relocations using a low-bed truck have been reported by Kärhä et al. [8] and Kauppinen [10].

The machines' operating interdependencies and the unique impact of worksite properties on machine performances in mechanized harvesting pose a challenge to conducting a reliable and realistic system analysis using deterministic/static methods, thus favoring the use of simulation methods such as DES (e.g., $[23,26,30])$. Due to the temporal dependencies of a harvester on the forwarder's performance, and a forwarder on the harvester's performance, related to machines' productivities, delays, and the timing of work shifts, machines may have an operational imbalance on a daily basis. Moreover, harvesting 
machines in the harvesting fleet depend on the relocation truck and its availability for the efficient flow of operations. When seasonal fluctuations of the trafficability of harvesting sites and gravel roads are added to the equation, the complexity of modeling mechanized harvesting systems increases. This may partly explain the relative lack of studies of the impact of operating models and business patterns, by analyzing, e.g., fleet size, fleet structure, available site reserve, the structure of site characteristics, harvesting regimes, and/or machine relocation models, on the operating performance and costs of wood harvesting entrepreneurs (e.g., [11,12,23]).

To assess the impact of alternative operating models and the scale of operations on the performance and costs of harvesting, simulations for annual harvesting scenarios were conducted using DES in typical harvesting conditions in Eastern Finland. The objectives of this study were to assess the impact of (i) the size of the harvesting fleet, (ii) the size of the site reserve, and (iii) the operating model of the harvesting entrepreneur's relocation truck on the performance parameters of machine operations, machine relocations, and harvesting costs. The harvesting entrepreneur's fleet size varied from 2 to $8 \mathrm{HUs}$, and all machine relocations were carried out by one relocation truck owned by the operator.

\section{Materials and Methods}

\subsection{Discrete-Event Simulation Method}

Mechanized CTL harvesting is a complex dynamic system involving several features, such as time and causal dependencies, uncertainty, stochasticity, highly varying working conditions, and non-linear behavior, which support the use of DES modeling, e.g., [20,26]. A harvester and a forwarder as a single operational unit face idling and imbalance in daily operations due to the variation in machine productivity and timber demand, worksite accessibility, and the timing and duration of machine breakdowns and machine relocations. An example of a method for smoothing the impact of a system imbalance on a daily basis is the use of adaptive work shifts for the harvester and forwarder. Moreover, selecting a feasible and time-saving method to conduct machine relocation for each harvesting situation decreases unnecessary machine idling. Instead of using deterministic system analysis, DES modeling was chosen for building and solving the system. The DES method, using simulation modeling software, Witness Horizon 21 [31], integrated with Excel spreadsheet control and the definition of initialized actions and scenario parameters, was used for this study (Figure 1).
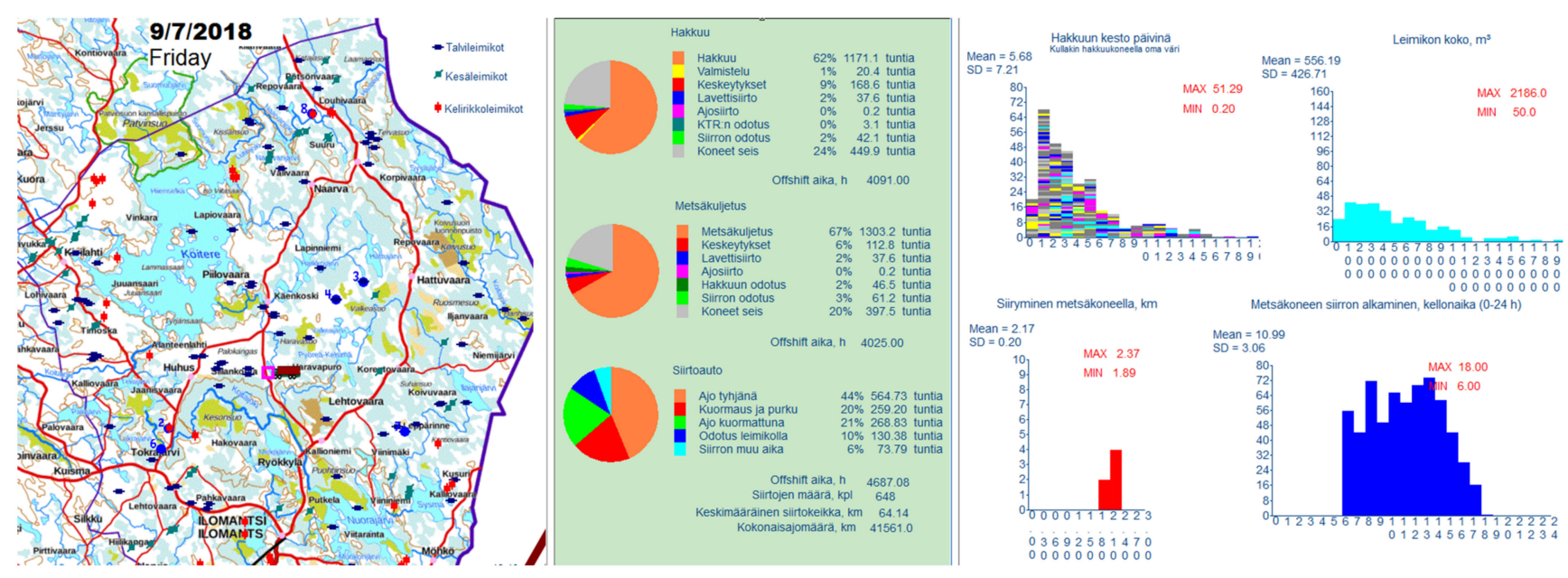

Figure 1. A screenshot of the visualized simulation model for operations of the wood harvesting entrepreneur modeled with Witness simulation software. The left panel of the figure illustrates the operating area with the harvesting sites at the site reserve, location of each numbered HU, and the movement of the relocation truck. The center panel presents the run-time specific work time distributions of machinery, and the right panel shows histograms of the harvesting data of interest. 


\subsection{Operating Environment}

The Ilomantsi region in Eastern Finland was selected for the case harvesting area from where the harvesting site data were obtained. The sample plot data from the National Forest inventory (NFI) measured in 2013-2017 [32] and the MELA software [33] were used to generate the harvesting site data, with harvesting compartments covering the regions of the municipalities of Ilomantsi and Lieksa. The MELA software is a forest decision support system developed for Finnish conditions for use in, e.g., large-scale management planning analyses and the estimation of felling possibilities [34]. The generated harvesting site data were based on the scenario of maximum economic removal (NT), with a $5 \%$ discount rate estimated for a 50-year period divided by five ten-year calculation periods (see [35]). The harvesting of energy wood was not included in the analysis, and to reflect the present situation of the shares of cutting regimes of timber harvesting, only the first ten-year period (2015-2024) was used to gather the required cutting treatments. After analysis, all inventory plot stands resulting in cutting treatment within the first ten-year period in the scenario were determined for the harvesting data, with one inventory plot stand representing one cutting compartment.

After MELA analysis and the selection of cutting compartments from the Ilomantsi and Lieksa regions, a spatial relocation for the compartments was generated randomly for the Ilomantsi region in forest land area. This procedure ensured a sufficiently high number of compartments for simulations of one year with the largest harvesting fleet scenario. As open-source spatial data, static trafficability classification was utilized to determine the harvesting season for each compartment [36]. Harvesting trafficability classes are based on seasonal changes in the bearing capacity of the forest floor in Finland [37]. The map provides an estimation of the season when harvesting operations may take place with standard harvesting machinery (i.e., a harvester and a forwarder) without causing substantial damage to the forest soil. The size of the data resolution was $16 \times 16 \mathrm{~m}$ pixels, each classified as follows:

1. Operations possible in all seasons;

2. Operations possible in summer, mineral soils;

3. Operations possible in a dry summer, mineral soils;

4. Operations possible in summer, peatlands;

5. Operations possible only in a dry summer, peatlands;

6. Operations possible only during frost or with a thick layer of snow;

7. Open water;

8. No data (missing airborne laser scanning (ALS) data).

The first six classes were rescaled to three classes of harvesting season, covering:

1. Thaw season sites (1. operations possible in all seasons);

2. Summer season sites (2. and 4. Operations possible in summer in mineral soils and peatlands); and

3. Winter or dry summer season sites (3., 5., and 6. Operations possible in a dry summer on both mineral soils and peatlands, and operations possible only during frost or with a thick layer of snow).

Having randomly generated the relocation of the harvesting compartments' center points, the harvesting season for each compartment was determined by the dominant classes counted within a $50 \mathrm{~m}$ radius drawn from the center point by ArcGIS. To generate harvesting sites with a varying number of cutting compartments (i.e., a harvesting site with 1 to 5 compartments with unique harvesting characteristics), a $1 \mathrm{~km}$ radius was used to cluster compartments by a certain harvesting season. Each of these clusters represented one harvesting site.

For each harvesting compartment, forwarding distance was estimated by analyzing the closest road connections with ArcGIS software and the national road and street database Digiroad [38]. The site-specific mean forwarding distance was derived by multiplying the Euclidean distance "from site to landing" by a winding factor of 1.4, which was estimated 
by taking the local terrain conditions and strip road network delineation into account as a fixed factor for all sites. The "from site to landing" distance referred to the shortest distance from the center of each harvesting compartment to the closest road segment. To obtain a representative harvesting removal distribution for the sites, a large forest machine entrepreneur operating in North Karelia and the volume removal data of harvesting sites and compartments over two years (2004 and 2007) were selected as a reference distribution for site and compartment volumes. The removals were then randomly distributed to the generated compartments by following the case entrepreneur's timber removal distribution.

According to descriptive statistics of the case entrepreneur's historical data from harvesting sites, most of the sites (95\%) consisted of between one and five cutting compartments with unique harvesting parameters, corresponding well to the range of the number of compartments (1-5) in the harvesting site data of simulations. The compartment data included the following characteristics: cutting removal $\left(\mathrm{m}^{3} /\right.$ compartment and $\left.\mathrm{m}^{3} / \mathrm{ha}\right)$; cutting regime (intermediate cutting (thinning and seed tree removal) or final felling); cutting area (ha); average stem size $\left(\mathrm{m}^{3}\right)$; removal (trees/ha); the proportion of broadleaved trees (\%); coordinates (N-coord, E-coord); and assortment-wise volumes $\left(\mathrm{m}^{3}\right)$.

\subsection{Modeling Machine Operations and Interactions}

The harvester and forwarder formed one operational harvesting unit (HU) for these operations, i.e., cutting and forwarding timber at the harvesting site. The harvesting machines modeled were "all-purpose" machines, enabling operation on all sites with the assumption that each machine had soft terrain gear to mount when required. As a base setting, the harvester and forwarder operated for six days per week in $8 \mathrm{~h}$ work shifts. However, due to the imbalance in machine performance between harvester and forwarder, the site- and machine-specific productivity differences were compensated for by adaptive work shift arrangements. If the cut timber volume lying at the site at a certain time (i.e., the cut volume yet to be extracted from the site to landing) reached a threshold value of $150 \mathrm{~m}^{3}$ (i.e., the site buffer limit) due to the higher daily productivity of the harvester compared to the forwarder, a work shift extension occurred for the forwarder. Typically, this occurred on final felling sites and sites with larger removable stems. The work shift extension was a maximum of $4 \mathrm{~h}$. However, if logs were extracted from the site to the landing before the set extension time, the work shift ended immediately (i.e., before the adjusted/extended working period). Alternatively, while the productivity of the harvester was $20 \%$ lower than that of the forwarder, the cut timber lying at the site was less than $50 \mathrm{~m}^{3}$, and there was more than $50 \mathrm{~m}^{3}$ timber to be cut at the site, a shift extension of $4 \mathrm{~h}$ was activated for the harvester at the end of the base shift. The harvester's base shift started at 6 a.m., the forwarder's at 7 a.m. The threshold values and shift adjustment options for the harvester and forwarder are presented in more detail in Table 1.

Table 1. Work shift arrangements of harvesters and forwarders for the working week.

\begin{tabular}{ccc}
\hline & Base Shift, Hours & Shift Extension, Max. Hours \\
\hline Mon & 8 & 4 \\
Tue & 8 & 4 \\
Wed & 8 & 4 \\
Fri & 8 & 4 \\
Thu & 8 & 4 \\
Sat & 8 & 4 \\
Sun & 0 & 0 \\
\hline
\end{tabular}

In this study, the work shift time of forest machine work equated to workplace time (WP) excluding time for travelling to/from workplace (i.e., work trip time), see, e.g., [39]. The workplace time was divided into a delay-free machine time (i.e., productive machine time; $\mathrm{PMH}$ or $\mathrm{E}_{0}$ ) and a delay time. Furthermore, the delay time was divided into a setup time (only for the harvester work), a relocation time (machine relocation either with the 
truck or with the machine itself), a waiting time (either waiting for the machine to complete the work, or waiting for the relocation to be started), and other delays. In addition to the delay-free machine time, machine time including delays with duration shorter than $15 \mathrm{~min}$ $\left(\mathrm{PMH}_{15}\right.$ or $\left.\mathrm{E}_{15}\right)$ were also monitored from the simulation runs. Machine utilization rate (MU\%), both for the harvester and the forwarder, was calculated by dividing $\mathrm{PMH}_{15}$ by the workplace time $\left(\mathrm{MU} \%=\mathrm{PMH}_{15} / \mathrm{WP} * 100\right)$.

For the cutting operation, separate time consumption functions for thinnings and final fellings were used (Tables 2 and 3, Figure 2). The coefficient values of the models presented by Väätäinen et al. [25] were rescaled to better match the productivity curves of the latest large follow-up study for harvesters in Finland [40] (Table 2). The site variables affecting cutting productivity were average stem size and stem removal per hectare of the site. On every site at the beginning of cutting, there was a setup time of $30 \mathrm{~min}$. This included the initialization of harvesting instructions for the new harvesting site. The time consumption function for the forwarding presented by Väätäinen et al. [25] was used in the model (Table 2), with the exception that the load size depended on the average stem size (Table 3), and the formula results were multiplied by 1.1. The variables influencing forwarding productivity in the formula were load size, forwarding distance, and removal per hectare at the site. Finally, both in cutting and forwarding, the time consumption was set to randomly vary within the proportional range of 0.9-1.1.

Table 2. Time consumption functions $\left(\mathrm{min} / \mathrm{m}^{3}\right)$ for the productive machine time $\left(\mathrm{PMH}, \mathrm{E}_{0}\right)$ for cutting and forwarding in the simulation model.

\begin{tabular}{cccc}
\hline Formula Type & Parameter & Form & Coefficient Value \\
\hline Cutting-thinning & coefficient- $\mathrm{b}_{0}$ & $\mathrm{~b}_{0}$ & 1.40 \\
& stem size- $\mathrm{x}_{1}, \mathrm{~m}^{3}$ & $1 / \mathrm{x}_{1}$ & 0.446 \\
& stem removal- $\mathrm{x}_{2}$, stems $/ \mathrm{ha}$ & $\mathrm{x}_{2}$ & -0.001 \\
Cutting-final felling & coefficient- $\mathrm{b}_{0}$ & $\mathrm{~b}_{0}$ & 1.24 \\
& stem size- $\mathrm{x}_{1}, \mathrm{~m}^{3}$ & $1 / \mathrm{x}_{1}$ & 0.37 \\
& stem removal- $\mathrm{x}_{2}$, stems $/ \mathrm{ha}$ & $\mathrm{x}_{2}$ & -0.00042 \\
Forwarding & coefficient- $\mathrm{b}_{0}$ & $\mathrm{~b}_{0}$ & 6.261 \\
& forwarding distance- $\mathrm{x}_{1}, \mathrm{~m}$ & $\mathrm{x}_{1} / \mathrm{x}_{2}$ & 0.029 \\
& load size- $\mathrm{x}_{2}, \mathrm{~m}^{3}$ & $\mathrm{x}_{2}$ & -0.046 \\
& load size $-\mathrm{x}_{2}, \mathrm{~m}^{3}$ & $\ln \left(\mathrm{x}_{3}\right)$ & -0.68 \\
\hline
\end{tabular}

Table 3. Defining of load size of the forwarder.

\begin{tabular}{cc}
\hline Stem Size- $\mathbf{x}_{\mathbf{1}}, \mathbf{~ m}^{\mathbf{3}}$ & ${\text { Load Size, } \mathbf{~}^{\mathbf{3}}}^{\mathbf{3}}$ \\
\hline $\mathrm{x}_{1}<0.07 \mathrm{~m}^{3}$ & 11 \\
$0.07 \mathrm{~m}^{3}<\mathrm{x}_{1}<0.125 \mathrm{~m}^{3}$ & 12 \\
$0.125 \mathrm{~m}^{3}<\mathrm{x}_{1}<0.25 \mathrm{~m}^{3}$ & 13 \\
$0.25 \mathrm{~m}^{3}<\mathrm{x}_{1}<0.45 \mathrm{~m}^{3}$ & 14 \\
$0.45 \mathrm{~m}^{3}<\mathrm{x}_{1}$ & 15 \\
\hline
\end{tabular}

For the duration and the occurrence of other delays, negative exponential distributions and lognormal distributions were used (Table 4). Other delays included coffee/meal breaks, communication activities, ICT management, and mechanical delays (i.e., service and repair). The parameter values used in Väätäinen et al. [25] were converted iteratively to better match the present technical utilization rate of forest machines by Jylhä et al. [40]. The process flow of machine operations in the simulation with the most decisive conditional sentences is expressed in Figure 3. 

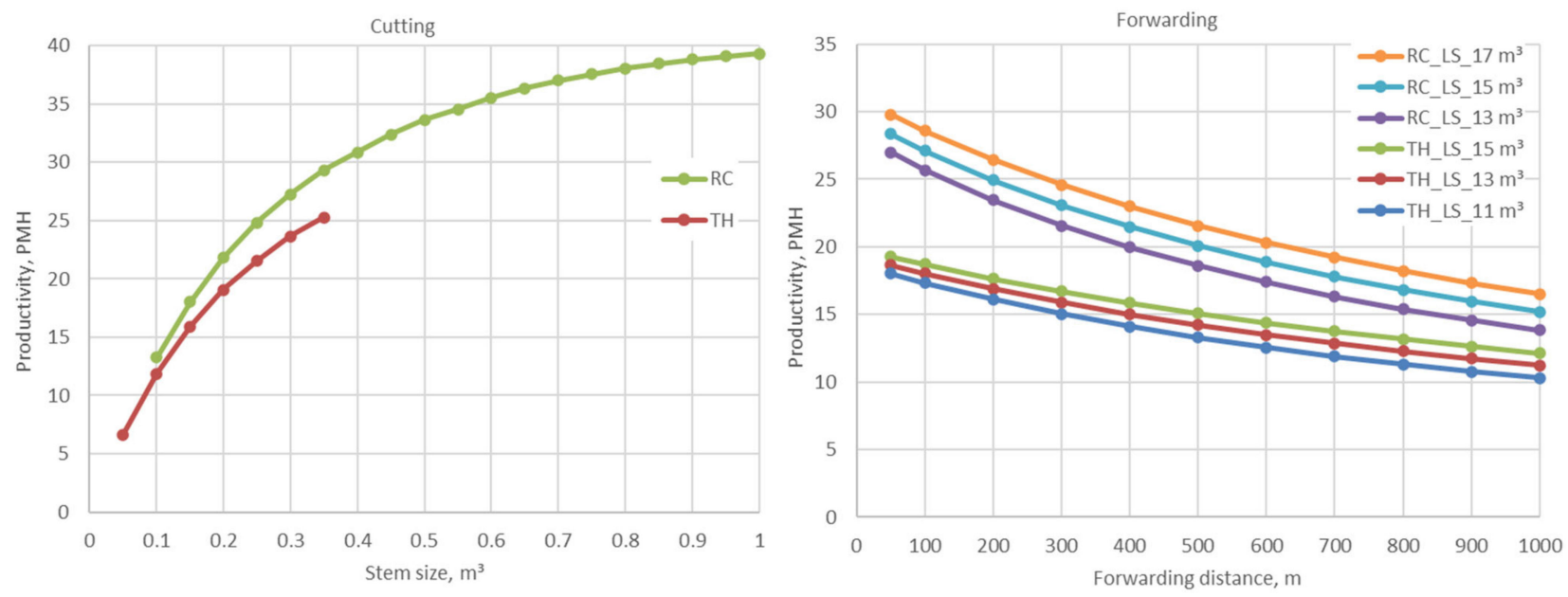

Figure 2. Productivity figures for the harvester and forwarder for the productive machine hour $\left(\mathrm{PMH}, \mathrm{E}_{0}\right)$ according to the time consumption formulas used. Average removals in volume and stems in thinnings (TH) were $88 \mathrm{~m}^{3} / \mathrm{ha}$ and 700 stems/ha, and in regeneration cuttings (RC) were $186 \mathrm{~m}^{3} /$ ha and 646 stems/ha. The size of load space (LS) varied between 11 and $15 \mathrm{~m}^{3}$.

Table 4. Specifications of probability distributions used for determining other delays.

\begin{tabular}{cccc}
\hline Time Between Delays & Type of Distribution & Mean, $\mathbf{h}$ & $\mathbf{S D}, \mathbf{h}$ \\
\hline harvester & Negative exponential & 1.97 & - \\
forwarder & Negative exponential & 3.1 & - \\
Duration of the Delay & & & 0.6 \\
\hline harvester & Lognormal & 0.28 & 0.45 \\
\hline forwarder & Lognormal & 0.25 & \\
\hline
\end{tabular}

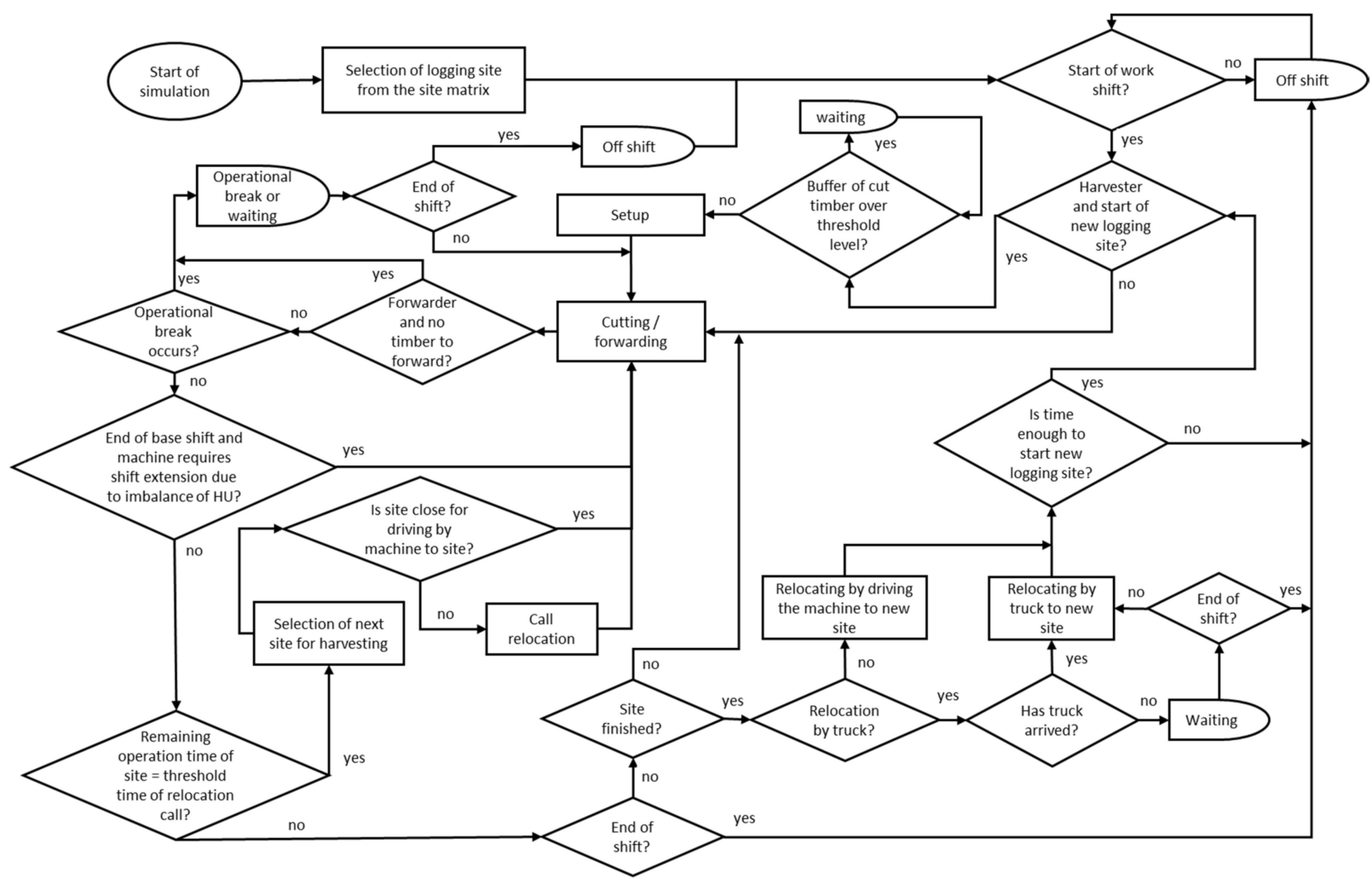

Figure 3. Flowchart of the process flow of machine operations (i.e., cutting by a harvester and forwarding by a forwarder), with the most decisive conditional expressions influencing operations. 
Depending on the size of the harvesting entrepreneur (i.e., the number of harvesting units) in each scenario, the base locations of machine operators and machines were designed according to Table 5 and Figure 4 . The base location of a relocation truck did not vary between scenarios. Harvesting machines were always relocated to a new site after the operation was finished at the harvesting site. This differed from the reality, where harvesting machines are relocated occasionally for maintenance and repairs, and for parking for longer non-operational periods (e.g., holiday seasons and lay-down days). The machine operators traveled from the base locations to the harvesting site on a daily basis.

Table 5. Base locations of machine/truck operators, harvesting units, and a relocation truck in the case harvesting area. The codes of locations are given in Figure 4.

\begin{tabular}{|c|c|c|c|c|}
\hline \multirow[b]{2}{*}{ Relocation Truck (RT) and Harvesting Unit (HU) } & \multicolumn{4}{|c|}{ Size of Harvesting Fleet (No. of Harvesting Units) } \\
\hline & 2 & 4 & 6 & 8 \\
\hline RT & A1 & A1 & A1 & A1 \\
\hline HU 1 & $\mathrm{~B} 2$ & B1 & B1 & B1 \\
\hline HU 2 & B5 & B3 & B2 & B1 \\
\hline HU 3 & & B4 & B3 & B3 \\
\hline HU 4 & & B6 & B4 & B3 \\
\hline HU 5 & & & B5 & B4 \\
\hline HU 6 & & & B6 & B4 \\
\hline HU 7 & & & & B6 \\
\hline HU 8 & & & & B6 \\
\hline
\end{tabular}

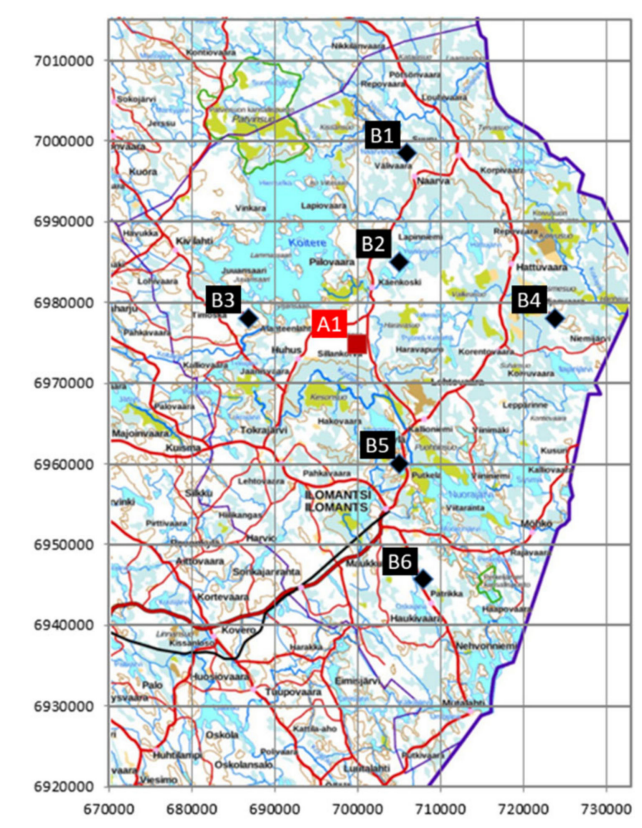

Figure 4. Base locations of machine/truck operators, harvesting units, and a relocation truck in the case harvesting area. The codes of locations are given in Table 5.

For the machine relocations between harvesting sites, a low bed truck with five axles was used (Table 1). The relocation truck started its work shift from the base location and returned at the end of the work shift. The winding factor for the machine relocations between the sites was set to 1.47 (i.e., the multiplicator for the Euclidean distance between sites), whereas the winding factor between the base location or the parking location and the harvesting site was 1.37. Winding factors were processed in ArcGIS by executing a search of a large number of road distances, both between harvesting sites, and between sites and the base location of the relocation truck, using the road data by Digiroad Finland. Two different adjustable work shifts were used for relocation operations: (i) a $12 \mathrm{~h}$ work 
shift; and (ii) an $8 \mathrm{~h}$ work shift plus a standby period until midnight (0:00 a.m.). Relocations during the standby period were expected to be carried out by the harvesting company's management personnel. The speed functions of the relocation truck for driving loaded and unloaded, and the time data for other work elements, were taken from the machine relocation study of Kauppinen [9]. The relocation truck's loading and unloading time was $0.2 \mathrm{~h}$ for each per relocation turn. On average, there was $0.1 \mathrm{~h}$ of auxiliary work time in each relocation cycle, with a deviation of 0.05 (TNorm $(0.1,0.05)$ ).

To run and control machine relocations, a CALL table was introduced to the simulation system. Machines were listed chronologically in the CALL table according to each machine's approximate finishing time of operations at the site. The threshold value for calling the relocation was $1.0 \mathrm{~h}$ before the estimated finishing time. The threshold value for each machine was calculated by the time consumption formulas for cutting or forwarding. Breakdowns of harvesting machines could not be activated during that time. At the start of the work shift, during breaks between relocations, and after the machine was relocated to a new site, the CALL table was always checked, and its order controlled the relocations during the day. On occasions when the CALL table was empty (i.e., no machines soon to be finished), the relocation truck was repositioned by $80 \%$ of the distance between the site and base location, toward the base location, to have a break for the next call. In very short relocation distances, the machines were relocated by driving them to the new site. Self-driving was activated in cases when the distance to the new site was either less than $1.2 \mathrm{~km}$ or within $1.2-2.5 \mathrm{~km}$ if the probability function RAND (0-1) resulted in more than $0.5(\operatorname{RAND}(0-1)>0.5)$.

\subsection{Site Matrixes}

The harvesting site data of simulation scenarios were distributed in various matrixes, depending on the need and purpose of the matrix in the simulation phase. The base site matrix (base matrix) consisted of all the harvesting sites and compartments converted and recalculated from the NFI data. According to the trafficability class of harvesting sites, the base matrix was divided into three matrixes based on the trafficability index. This process was accomplished immediately after the site order randomization of the base matrix, but before the start of every replication run. The active site matrix (active matrix) was the simulation process-dependent matrix, which utilized harvesting site and compartment data by the trafficability class-based matrixes. The number of harvesting sites of each trafficability class within the active matrix was able to be adjusted for the simulation scenarios. Both the trafficability of harvesting sites (i.e., harvesting season) and the timing of lay-down times (e.g., holidays) were defined by week (Table 6).

In initialization actions, where the base parametrization was designed covering all simulation scenarios, the demand for timber over the harvesting period (one year) was defined. The proportions of the demands for each timber assortment were set as fixed through the year, and the volumes of assortments corresponded to cumulative timber volumes of the base matrix of the harvesting sites in Ilomantsi. In total, six timber assortments were harvested with the following proportions: pine sawnwood $(28.5 \%)$; spruce sawnwood (12.7\%); birch veneer wood (1.2\%); pine pulpwood (33.0\%); spruce pulpwood $(10.0 \%)$; and birch pulpwood (14.6\%). The biggest demand gap within timber assortments was the most decisive factor in searching for the next harvesting site to be harvested at a certain simulation time. For each harvesting unit, the predetermined procedure with the set of preconditions was conducted when defining the next harvesting site to be harvested. This procedure was always executed before the call of the relocation truck to check the need for machine relocation by truck (short distances by the self-driving of machines). The selected harvesting site was saved for the harvester in question. The conditional expression involved checking (i) the current timber demand, (ii) the volumes of the site's timber assortments, (iii) the site's accessibility (i.e., harvestability), (iv) the site's location, (v) the harvesting unit's operating area, and (vi) how long the site had been in the active site matrix. In particular, in the scenarios with a bigger harvesting site reserve, if two 
or more harvesting sites with the same coordinates selectable for harvesting were found, the model treated these sites as one site, and the removal per site thereby increased. The core operating area of each $\mathrm{HU}$ was determined by a $25 \mathrm{~km}$ radius distance from the base location. Harvesting outside of the core area of each $\mathrm{HU}$ was possible only if any suitable sites were unavailable inside the area. Figure 5 presents the order of conditional expression.

Table 6. Harvesting trafficability and rest times by week in the simulations. Harvesting trafficability indexes: $1=$ summer sites, 2 = winter and dry summer sites, and 3 = thaw season sites. "Work" corresponds to the normal work week and "Rest" to lay-down times (e.g., holiday seasons).

\begin{tabular}{|c|c|c|c|c|c|c|c|c|c|c|c|}
\hline Month & Week & Trafficability & Mode & Month & Week & Trafficability & Mode & Month & Week & Trafficability & Mode \\
\hline Jan & 1 & 2 & Work & May & 21 & 1 & Work & Oct & 41 & 1 & Work \\
\hline Jan & 2 & 2 & Work & May & 22 & 1 & Work & Oct & 42 & 1 & Work \\
\hline Jan & 3 & 2 & Work & June & 23 & 1 & Work & Oct & 43 & 3 & Work \\
\hline Jan & 4 & 2 & Work & June & 24 & - & Rest & Now & 44 & 1 & Work \\
\hline Feb & 5 & 2 & Work & June & 25 & 2 & Work & Now & 45 & 1 & Work \\
\hline Feb & 6 & 2 & Work & June & 26 & - & Rest & Now & 46 & 3 & Work \\
\hline Feb & 7 & 2 & Work & July & 27 & - & Rest & Now & 47 & 3 & Work \\
\hline Feb & 8 & 2 & Work & July & 28 & - & Rest & Now & 48 & 3 & Work \\
\hline March & 9 & 2 & Work & July & 29 & - & Rest & Dec & 49 & 2 & Work \\
\hline March & 10 & 2 & Work & July & 30 & - & Rest & Dec & 50 & 2 & Work \\
\hline March & 11 & 2 & Work & Aug & 31 & 1 & Work & Dec & 51 & 2 & Work \\
\hline March & 12 & 2 & Work & Aug & 32 & 2 & Work & Dec & 52 & - & Rest \\
\hline March & 13 & 2 & Work & Aug & 33 & 1 & Work & & & & \\
\hline April & 14 & 2 & Work & Aug & 34 & 1 & Work & & & & \\
\hline April & 15 & 3 & Work & Aug & 35 & 1 & Work & & & & \\
\hline April & 16 & 3 & Work & Sept & 36 & 1 & Work & & & & \\
\hline April & 17 & 3 & Work & Sept & 37 & 1 & Work & & & & \\
\hline May & 18 & - & Rest & Sept & 38 & 1 & Work & & & & \\
\hline May & 19 & - & Rest & Sept & 39 & 1 & Work & & & & \\
\hline May & 20 & 1 & Work & Oct & 40 & 1 & Work & & & & \\
\hline
\end{tabular}

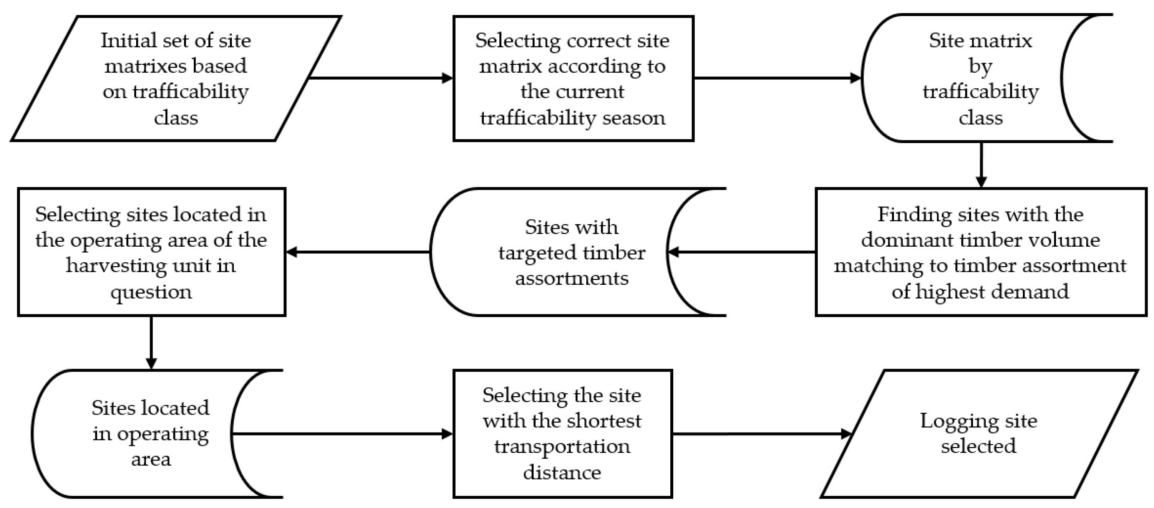

Figure 5. Site selection principle for next site to be harvested.

\subsection{Simulation Scenarios and Cost Calculations}

Three main simulation scenarios were configured. Scenario A consisted of the size of the fleet of a harvesting entrepreneur, scenario B consisted of the size of the available harvesting site reserve, and scenario $C$ compared the timing and work shift options of machine relocations (Table 7). All main scenarios included an operating mode for machine relocations in which a separate driver was recruited to work with an $8 \mathrm{~h}$ nominal work shift starting at 6 a.m., and if machine relocations needed to be carried out after that, one of the harvesting company's management personnel took responsibility for the relocation within the next 4 or $10 \mathrm{~h}$, depending on the sub-scenario. In scenarios $\mathrm{A}$ and $\mathrm{C}$, options for accomplishing all machine relocations by the management personnel of the company were also included. With this option, salary costs were not included in machine relocation costs, 
and the control logic of machine relocations in the system were the same with or without the separate driver.

Table 7. Simulation scenarios of the study.

\begin{tabular}{|c|c|c|}
\hline Main Scenario & Sub Scenario & Definition \\
\hline \multirow{4}{*}{$\begin{array}{l}\text { A. Size of the } \\
\text { fleet } 1,3\end{array}$} & $2 \mathrm{HU}$ & 2 HUs with a relocation truck and a 0.9-month site buffer \\
\hline & $4 \mathrm{HU}$ & 4 HUs with a relocation truck and a 0.9 -month site buffer \\
\hline & $6 \mathrm{HU}$ & 6 HUs with a relocation truck and a 0.9 -month site buffer \\
\hline & $8 \mathrm{HU}$ & 8 HUs with a relocation truck and a 0.9 -month site buffer \\
\hline \multirow{8}{*}{$\begin{array}{l}\text { B. Size of } \\
\text { harvesting site } \\
\text { reserve }^{1}\end{array}$} & $0.23 \mathrm{mths} \_4 \mathrm{HU}$ & 4 HUs with a relocation truck and a 0.23 -month site buffer \\
\hline & $0.45 \mathrm{~m} t h s \_4 \mathrm{HU}$ & 4 HUs with a relocation truck and a 0.45 -month site buffer \\
\hline & $0.9 \mathrm{mths} 4 \mathrm{HU}$ & 4 HUs with a relocation truck and a 0.9-month site buffer \\
\hline & $1.75 \mathrm{~m} t \mathrm{hs}$ 44HU & 4 HUs with a relocation truck and a 1.75 -month site buffer \\
\hline & $0.23 \mathrm{mths} \_8 \mathrm{HU}$ & 8 HUs with a relocation truck and a 0.23 -month site buffer \\
\hline & $0.45 \mathrm{~m}$ ths_8HU & 8 HUs with a relocation truck and a 0.45 -month site buffer \\
\hline & $0.9 \mathrm{mths} \_8 \mathrm{HU}$ & 8 HUs with a relocation truck and a 0.9 -month site buffer \\
\hline & 1.75mths_8HU & 8 HUs with a relocation truck and a 1.75-month site buffer \\
\hline \multirow{6}{*}{$\begin{array}{l}\text { C. Timing of } \\
\text { machine } \\
\text { relocations }\end{array}$} & 8h+4h-stby_4HU & 4 HUS with a relocation truck and 8 -h work shift, with an additional $4 \mathrm{~h}$ as standby 2 \\
\hline & $8 \mathrm{~h}+10 \mathrm{~h}-\mathrm{stby} 4 \mathrm{HU}$ & 4 HUs with a relocation truck and 8-h work shift, with an additional $10 \mathrm{~h}$ as standby 1 \\
\hline & 18h-stby_4HU & 4 HUs with a relocation truck and 18-h as standby ${ }^{3}$ \\
\hline & 8h+4h-stby_8HU & $8 \mathrm{HUs}$ with a relocation truck and 8 -h work shift, with an additional $4 \mathrm{~h}$ as standby ${ }^{2}$ \\
\hline & $8 \mathrm{~h}+10 \mathrm{~h}-\mathrm{stby} 8 \mathrm{HU}$ & 8 HUs with a relocation truck and 8-h work shift, with an additional $10 \mathrm{~h}$ as standby 1 \\
\hline & 18h-stby_8HU & 8 HUs with a relocation truck and $18 \mathrm{~h}$ as standby ${ }^{3}$ \\
\hline
\end{tabular}

\footnotetext{
${ }^{1}$ Separate person recruited for machine relocation with 8-h work shift and remaining daily relocations within next $10 \mathrm{~h}$ by company's management personnel; ${ }^{2}$ Separate person recruited for machine relocation with 8 -h work shift and remaining daily relocations within next $4 \mathrm{~h}$ by company's management personnel; ${ }^{3}$ Company's own personnel take responsibility for machine relocations; salary costs of relocations embedded in harvesting costs.
}

In scenario A, the fleet sizes of 2, 4, 6, and 8 HUs were simulated. The average harvesting site reserve was set at 0.9 months for all sub-scenarios. Daily machine relocations were carried out within $18 \mathrm{~h}$, either with the option of an $8 \mathrm{~h}$ separate driver and an additional $10 \mathrm{~h}$ standby, or with the $18 \mathrm{~h}$ standby option with the company's management personnel. In the latter case, the salary cost for relocation was not included in the relocation costs. In scenario $B$, the average harvesting site reserve varied between $0.23,0.45,0.9$, and 1.75 months for the two fleet size scenarios of 4 and $8 \mathrm{HU}$. All scenario B sub-scenarios included an $8 \mathrm{~h}$ separate truck driver for conducting machine relocations added to a $10 \mathrm{~h}$ standby/availability for required relocations during the remainder of the day. In scenario $\mathrm{C}$, the day's machine relocations were carried out either during a 12 or $18 \mathrm{~h}$ period, starting at 6 a.m. In the $12 \mathrm{~h}$ working option, an $8 \mathrm{~h}$ work shift of a separate low bed truck driver was used, and the remaining relocations were performed by the entrepreneur's personnel within a $4 \mathrm{~h}$ standby time ( $8 \mathrm{~h}+4 \mathrm{~h}$-stby). In $18 \mathrm{~h}$ options, a combination of an $8 \mathrm{~h}$ separate driver and a $10 \mathrm{~h}$ additional standby time $(8 \mathrm{~h}+10 \mathrm{~h}$-stby) or a full $18 \mathrm{~h}$ standby time operated by the company's management personnel (18h-stby) was used. Simulation runs for the $\mathrm{C}$ scenarios were carried out for two fleet sizes of 4 and $8 \mathrm{HU}$, and with a harvesting site reserve of 0.9 months.

The simulation scenario run was for one full year, starting on 1 January. Each of the simulation scenarios was replicated seven times, and the average of the replications was used in the results to control the replication variation. In addition, $95 \%$ confidence levels (CL) were given as the main result indicators for scenarios. Between replications, random seeds were varied in all theoretical distributions and random number generators. Due to the variation of harvesting site parameters and the impact of the order of harvesting sites in the base site matrix, harvesting sites were randomly rearranged at the beginning of each replication run. This procedure restructured the harvesting operations for every replication, thereby ensuring the yearly variation was consistent with that in reality.

Machine-specific costing table sheets were used for cutting, forwarding, and machine relocations. The cost for each machine type was conducted on an annual basis. The 
cost of cutting was determined by the time consumption and cutting performance data of harvesters from the set of simulation scenario runs, and the cost of forwarding and machine relocations followed the same procedure. Price values represented average values for 2018, and were collected from statistics and harvesting entrepreneurs operating in Eastern Finland. Machine operators' work trips were monitored from home to work and back, and trip allowances were counted. The operators' home locations were the same as the base locations of the harvesting machines each operator was using. Cost-specific data is available in Table 8 .

Table 8. Cost accounting factors and the values (excluding VAT) used for calculating costs of the harvesting operations.

\begin{tabular}{|c|c|c|c|}
\hline Characteristics of Machinery & Harvester & Forwarder & Low-bed Truck \\
\hline Size in weight, $\mathrm{t}$ & $17-20$ & $15-18$ & $15 \mathrm{t}$ \\
\hline Gross vehicle weight, $\mathrm{t}$ & - & $28-32$ & 44 \\
\hline Axles, no. & bogie axles in front and & bogie axles in front and & 5-axles \\
\hline Purchase price (incl. equipment), $€$ & 465,000 & 320,000 & 221,900 \\
\hline Soft soil gear (equipment), $€$ & 15,000 & 20,000 & $\begin{array}{c}- \\
2 L 1,>00\end{array}$ \\
\hline Harvester head (equipment), $€$ & 60,000 & 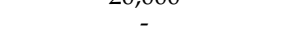 & - \\
\hline Life span (base machine; equipment) & $12,000 \mathrm{~h} ; 7000 \mathrm{~h}$ & $15,000 \mathrm{~h} ; 7000 \mathrm{~h}$ & 10 years $(240 \mathrm{k}-770 \mathrm{k} \mathrm{km})$ \\
\hline Salvage percent (base machine; equipment), \% & $23 ; 20$ & $23 ; 20$ & \\
\hline $\begin{array}{l}\text { Annual depreciation of purchase price, } \% \\
\text { Fixed costs }\end{array}$ & & & 20 \\
\hline Interest rate, $\%$ & 3 & 3 & 3 \\
\hline Insurance and trafficking costs, $€$ & 2000 & 1500 & 2500 \\
\hline $\begin{array}{c}\text { Adm., maint., and buildings ( } 2 \mathrm{HU} ; 4 \mathrm{HU} ; 6 \mathrm{HU} ; 8 \mathrm{HU}), \mathrm{k} € \\
\text { Labour costs }\end{array}$ & $4 ; 2.5 ; 2 ; 1.75$ & $4 ; 2.5 ; 2 ; 1.75$ & 3 \\
\hline Wage cost for base shift, $€ / \mathrm{h}$ & 15 & 14 & 14 \\
\hline Wage cost for weekend/extended shift, $€ / \mathrm{h}$ & 24 & 22.5 & - \\
\hline Indirect wage cost, $\%$ & 57 & 57 & 57 \\
\hline Kilometer allowance for machine operators, $€ / \mathrm{km}$ & 0.43 & 0.43 & - \\
\hline $\begin{array}{c}\text { Daily allowance for machine operators, } € \text { / day on avg. } \\
\text { Variable costs }\end{array}$ & 5 & 5 & - \\
\hline Fuel price and consumption & $€ 0.89 / \mathrm{L} ; 16 \mathrm{~L} / \mathrm{h}$ & $€ 0.89 / \mathrm{L} ; 13 \mathrm{~L} / \mathrm{h}$ & $€ 1.1 / \mathrm{L} ; 40 \mathrm{~L} / \mathrm{km}$ \\
\hline Engine and gear oil price and consumption & $€ 1.29 / \mathrm{L} ; 0.1 \mathrm{~L} / \mathrm{h}$ & $€ 1.29 / \mathrm{L} ; 0.1 \mathrm{~L} / \mathrm{h}$ & $€ 0.01 / \mathrm{km}$ \\
\hline Hydraulic oil price and consumption & $€ 1.69 / \mathrm{L} ; 0.2 \mathrm{~L} / \mathrm{h}$ & $€ 1.69 / \mathrm{L} ; 0.2 \mathrm{~L} / \mathrm{h}$ & - \\
\hline Chainsaw oil price and consumption & $€ 1.69 / \mathrm{L} ; 0.57 \mathrm{~L} / \mathrm{h}$ & - & - \\
\hline Color mark price and consumption & $€ 1.29 / \mathrm{L} ; 0.3 \mathrm{~L} / \mathrm{h}$ & - & - \\
\hline Chainsaw price and consumption & $€ 16.1 / \mathrm{pcs} ; 0.06 \mathrm{pcs} / \mathrm{h}$ & - & - \\
\hline Sawbar price and consumption & $€ 50 / \mathrm{pcs} ; 0.02$ pcs $/ \mathrm{h}$ & - & - \\
\hline Repair and maintenance cost & $€ 12.1 / \mathrm{h}$ & $€ 8.06 / \mathrm{h}$ & $€ 0.1 / \mathrm{km}$ \\
\hline Tire coating, $€ /$ tyre & - & - & 300 \\
\hline Max distance for tires before coating, $\mathrm{km}$ & - & - & 100,000 \\
\hline Operating margin, $\%$ & 5 & 5 & 5 \\
\hline
\end{tabular}

\section{Results}

\subsection{Size of the Fleet}

The mean values of harvesting site characteristics (i.e., site removal, site area, stem size, and forwarding distance) did not differ significantly among simulation scenario runs (Table 9). The mean annual harvesting volume of a harvesting unit was within $36,273-37,220 \mathrm{~m}^{3}$. The size of the harvesting fleet therefore did not affect the volume. In all scenarios, the average harvesting site reserve for one harvester-forwarder unit was adjusted to 0.9 months (i.e., the average duration for harvesting the wood volume of sites at the site reserve). However, the site reserve varied during the one-year simulation, and was at its lowest for 0.3-0.4 months during the thaw and summer periods, and at its highest for 1.0-1.2 months during the winter.

The efficiency and utilization figures noticeably improved for the relocation truck when the size of the fleet increased (Table 10). The mean operating time of the truck increased from 2.3 to $7.3 \mathrm{~h}$ per day $(+217 \%)$ when the size of the fleet increased from 2 to $8 \mathrm{HUs}(+300 \%)$. The average trip length and time decreased from 82 to $64 \mathrm{~km}$ and 2.3 to $1.9 \mathrm{~h}$, due mainly to the larger site reserve with shorter site-to-site machine relocations. 
Table 9. Parameter data of harvesting sites and machine performance among simulation scenarios of 2, 4, 6, and $8 \mathrm{HU}$. Presented are $95 \%$ confidence intervals of 7 replications.

\begin{tabular}{|c|c|c|c|c|c|c|c|c|}
\hline & \multicolumn{2}{|c|}{$2 \mathrm{HU}$} & \multicolumn{2}{|c|}{$4 \mathrm{HU}$} & \multicolumn{2}{|c|}{$6 \mathrm{HU}$} & \multicolumn{2}{|c|}{$8 \mathrm{HU}$} \\
\hline & AVG & CI-95\% & AVG & CI-95\% & AVG & CI-95\% & AVG & CI-95\% \\
\hline Site removal, $\mathrm{m}^{3}$ & 571.6 & \pm 27.4 & 600.3 & \pm 28.8 & 587.1 & \pm 19.7 & 592.2 & \pm 18.7 \\
\hline Harvesting site area, ha & 5.2 & \pm 0.25 & 5.5 & \pm 0.3 & 5.3 & \pm 0.24 & 5.4 & \pm 0.15 \\
\hline Stem size, $\mathrm{m}^{3}$ & 0.250 & \pm 0.011 & 0.252 & \pm 0.004 & 0.255 & \pm 0.004 & 0.255 & \pm 0.003 \\
\hline Forwarding distance, $\mathrm{m}$ & 353 & \pm 29 & 356 & \pm 14.8 & 338 & \pm 11.4 & 335 & \pm 8.7 \\
\hline No. of logging sites & 127 & \pm 5.98 & 249 & \pm 10.23 & 378 & \pm 11.77 & 498 & \pm 11.17 \\
\hline Cutting productivity, average, $\mathrm{m}^{3} / \mathrm{PMH}_{15}$ & 18.8 & \pm 0.64 & 19.4 & \pm 0.13 & 19.3 & \pm 0.25 & 19.2 & \pm 0.22 \\
\hline Forwarding productivity, $\mathrm{m}^{3} / \mathrm{PMH}_{15}$ & 16.6 & \pm 0.69 & 16.7 & \pm 0.17 & 17.1 & \pm 0.31 & 17.0 & \pm 0.18 \\
\hline Total removal, $\mathrm{m}^{3}$ & 72,546 & \pm 1986 & 148,882 & \pm 1032 & 221,577 & \pm 2401 & 294,255 & \pm 3741 \\
\hline Removal per $\mathrm{HU}, \mathrm{m}^{3}$ & $36,272.9$ & & $37,220.4$ & & $36,929.6$ & & $36,781.9$ & \\
\hline Harvesting site reserve, average, $\mathrm{m}^{3}$ & 5844 & & 12,169 & & 18,320 & & 24,020 & \\
\hline Harvesting site reserve average in months & 0.89 & & 0.90 & & 0.91 & & 0.90 & \\
\hline
\end{tabular}

Table 10. Performance values of the relocation truck among simulation scenarios of 2, 4, 6, and 8 HU. Presented are $95 \%$ confidence intervals of 7 replications.

\begin{tabular}{|c|c|c|c|c|c|c|c|c|}
\hline & \multicolumn{2}{|c|}{$2 \mathrm{HU}$} & \multicolumn{2}{|c|}{$4 \mathrm{HU}$} & \multicolumn{2}{|c|}{$6 \mathrm{HU}$} & \multicolumn{2}{|c|}{$8 \mathrm{HU}$} \\
\hline & AVG & CI-95\% & AVG & CI-95\% & AVG & CI-95\% & AVG & CI-95\% \\
\hline Operation time of the day, hours & 2.3 & \pm 0.18 & 4.0 & \pm 0.18 & 5.8 & \pm 0.21 & 7.3 & 0.2 \\
\hline No. of relocations, no./year & 252 & \pm 12 & 492 & \pm 21 & 741 & \pm 24 & 971 & \pm 24 \\
\hline Total driving, km/year & 20,580 & \pm 1655 & 34,995 & \pm 1398 & 50,462 & \pm 2470 & 62,039 & \pm 1414 \\
\hline Average relocation distance, $\mathrm{km}$ & 30.0 & \pm 2.0 & 22.0 & \pm 1.0 & 19.9 & \pm 0.9 & 16.7 & \pm 0.5 \\
\hline Average cycle trip, $\mathrm{km}$ & 81.6 & \pm 2.7 & 71.1 & \pm 1.1 & 68.1 & \pm 1.5 & 63.9 & \pm 0.8 \\
\hline Average trip time, $\mathrm{h}$ & 2.3 & \pm 0.07 & 2.1 & \pm 0.03 & 2.0 & \pm 0.03 & 1.9 & \pm 0.04 \\
\hline Relocations by harvesting machine, no/year & 0.7 & \pm 0.7 & 0.7 & \pm 0.5 & 1.3 & \pm 0.3 & 1.5 & \pm 0.4 \\
\hline
\end{tabular}

$\mathrm{PMH}_{15}$ time for the harvester work took nearly the same share of the workplace time regardless of the size of the fleet (MU\% was $85.3 \%, 85.3 \%, 84.8 \%$, and $84.9 \%$ for $2,4,6$, and $8 \mathrm{HU}$, respectively). Similar results were seen for the MU\% of forwarding, with shares of $87.9 \%, 88.3 \%, 88.0 \%$, and $87.4 \%$ in the respective order of scenarios. The larger the fleet, the smaller the machine relocation time, and the longer the wait for the relocation for both the harvester and the forwarder (Figures 6 and 7). Therefore, due to the opposite directions of the impact on the wait for the relocation time and the machine relocation time, the size of the fleet basically had no influence on the MU\% of machines.

With a larger fleet size, due to the greater availability of closer harvesting sites, the relocation distance between sites decreased compared to smaller fleet sizes (Figure 8). For example, the $2 \mathrm{HU}$ scenario resulted in $40 \%$, and the $8 \mathrm{HU}$ scenario resulted in $73 \%$, of all relocations by the low-bed truck in relocation distances of less than $20.1 \mathrm{~km}$.

Largely because of the lower use of the relocation truck, particularly in the $2 \mathrm{HU}$ scenario, harvesting costs were $9.0 \%$ and $6.1 \%$ higher compared to the $4 \mathrm{HU}$ scenarios, and $12.8 \%$ and $8.3 \%$ higher compared to the $8 \mathrm{HU}$ scenarios, with and without a designated driver and the salary cost for the relocation truck, respectively (Figure 9). Moreover, with a smaller fleet size, the unit costs of harvesting machines $\left(\mathrm{EUR} / \mathrm{m}^{3}\right)$ were slightly higher due to longer work trips to sites further from home with higher work trip expenses, and a slightly higher share of administration and maintenance costs divided by the smaller number of machines. If a driver was not recruited for machine relocations, and salary costs were excluded from the relocation costs, the financial impact was significantly better in smaller fleet scenarios. The decrease in harvesting costs for 2, 4, 6, and $8 \mathrm{HU}$ was $5.5 \%$, $2.9 \%, 2.0 \%$, and $1.5 \%$, respectively. 


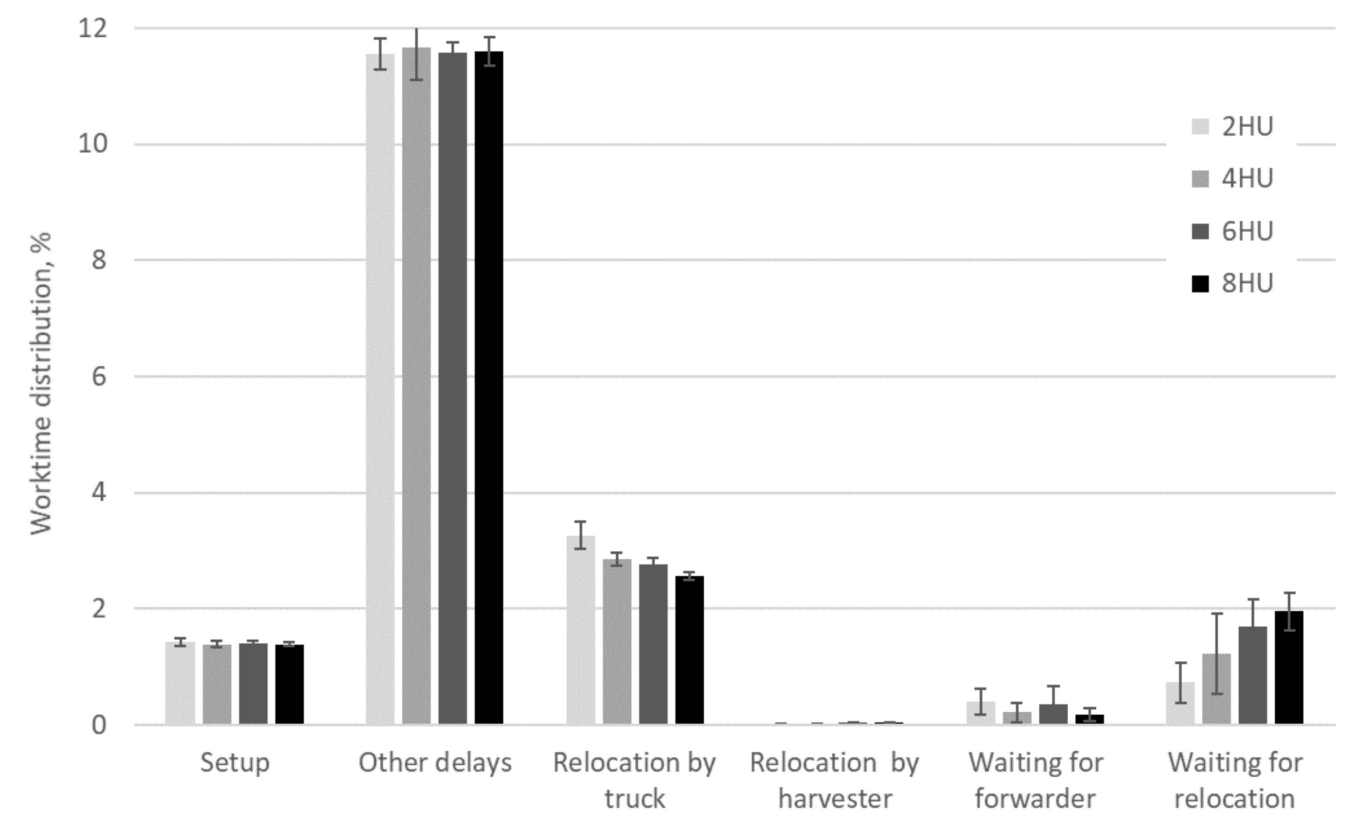

Figure 6. Worktime distributions for smaller time elements of harvesters with $95 \%$ confidence intervals. The entrepreneur's fleet size ranged between 2 and 8 harvesting units (HU).

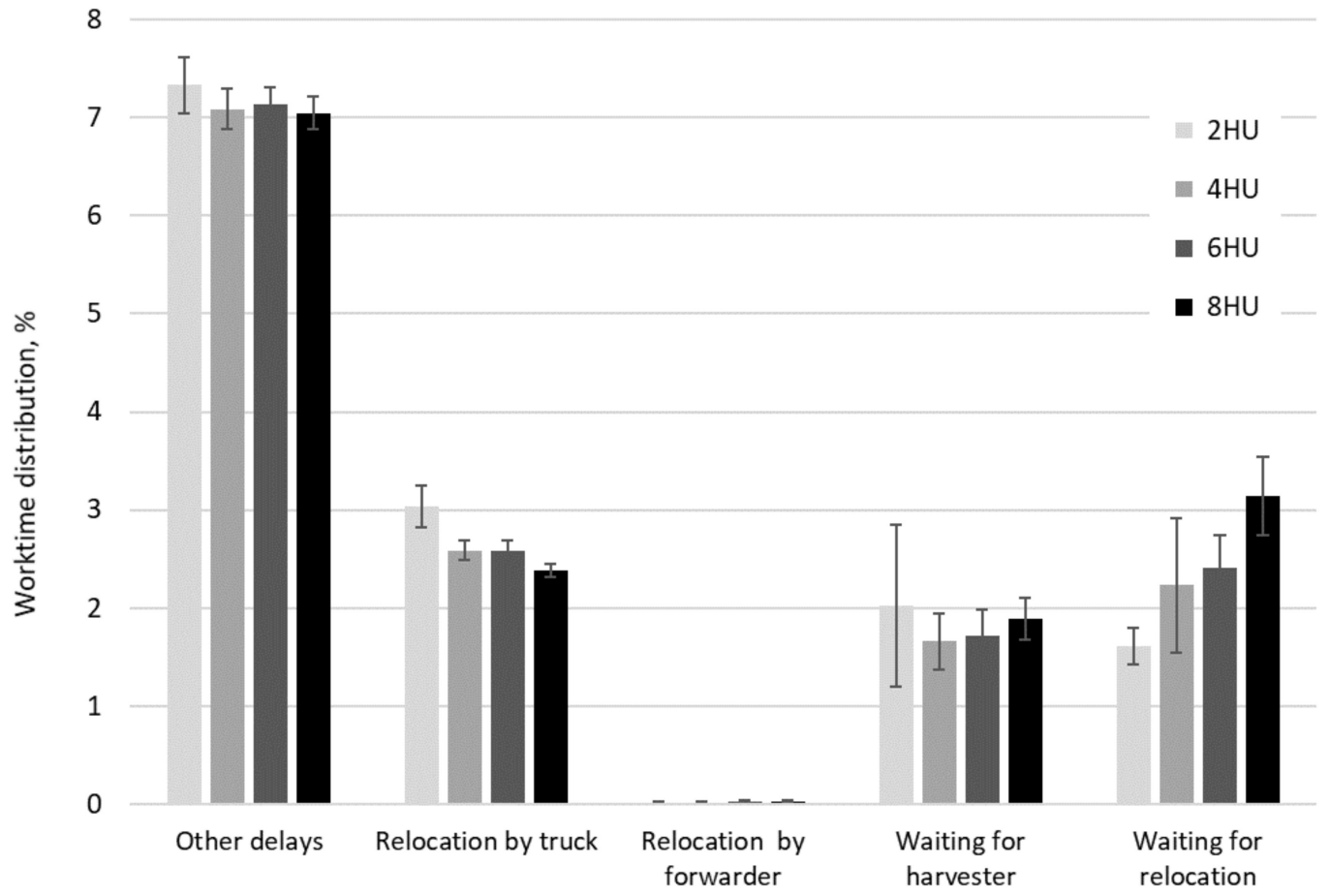

Figure 7. Work time distributions for smaller time elements of forwarders with $95 \%$ confidence intervals. The entrepreneur's fleet size ranged between 2 and 8 harvesting units (HU). 


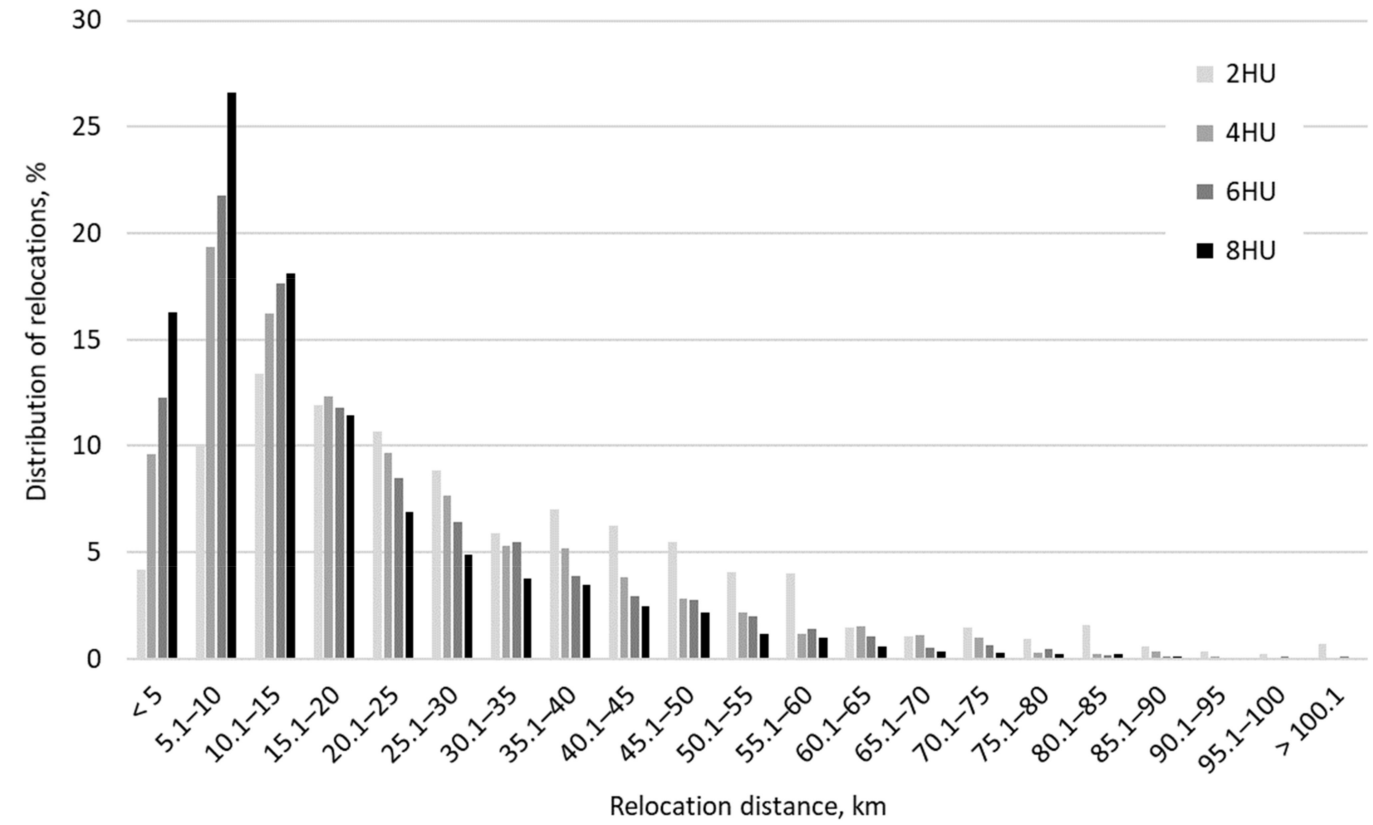

Figure 8. Distance distributions of machine relocations by low-bed truck for the fleet size scenarios $(2,4,6$, and $8 \mathrm{HU})$. The scenario bars represent averages of 7 replications.

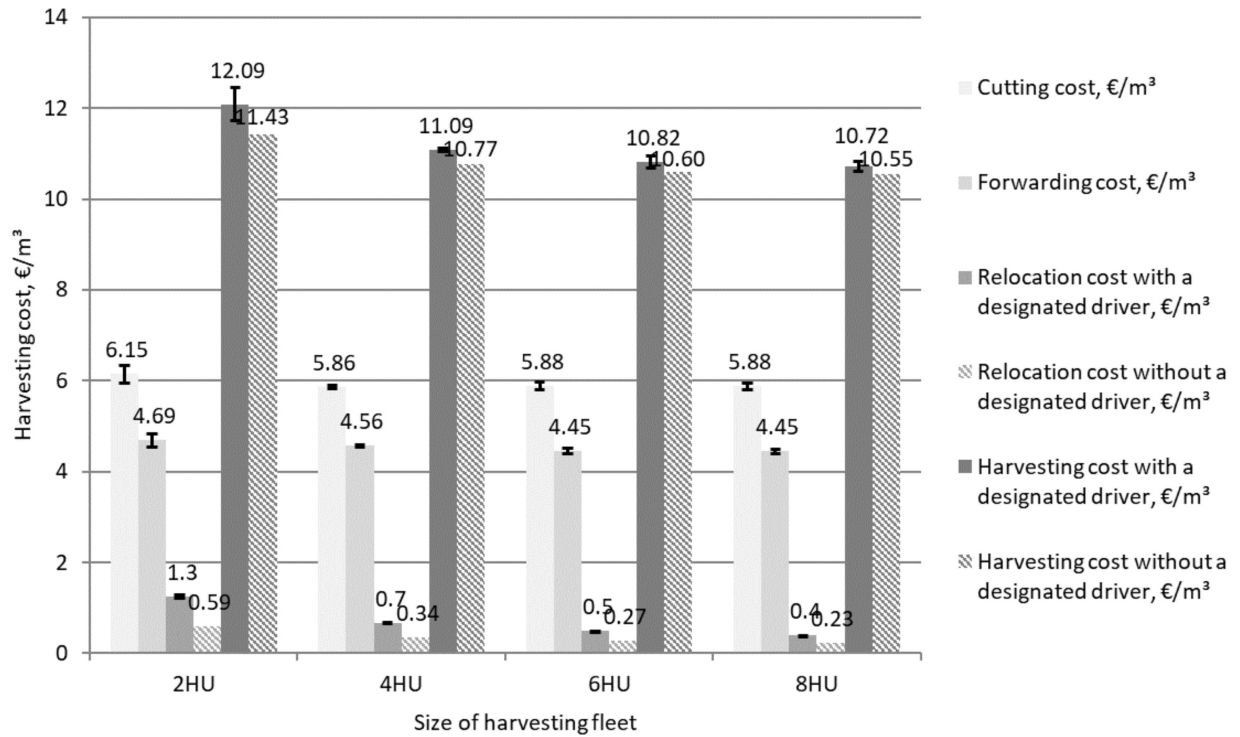

Figure 9. Harvesting costs for the scenarios of various fleet sizes $(2,4,6$, and $8 \mathrm{HU})$. Error bars represent the $95 \% \mathrm{CI}$ of 7 scenario replications. In addition, both the relocation and the harvesting costs are expressed with and without a specially employed driver for the relocation truck.

\subsection{Size of Harvesting Site Reserve}

A larger harvesting site reserve, measured in months, significantly decreased both the mean relocation distance and the time share for machine relocations (Figure 10). Moreover, waiting times for the relocations dropped noticeably. The 0.23 -month scenario ( 1 week) harvesting site reserve for 4 HUs resulted in a $208 \%$ longer mean relocation distance compared to a 1.75 -month site reserve ( $33.1 \mathrm{~km}$ for $0.23 \mathrm{mths}$ vs. $15.9 \mathrm{~km}$ for $1.75 \mathrm{mths}$ ), whereas the respective value in the $8 \mathrm{HU}$ scenario run was $234 \%$ ( $29.2 \mathrm{~km}$ for $0.23 \mathrm{mths}$ vs. $12.5 \mathrm{~km}$ for $1.75 \mathrm{mths})$. Productive operating times for cutting and forwarding increased by roughly $1.5 \%$ with the respective increase in the average site reserve ( 0.23 to 1.75 months). 
In addition, more efficient clustering of harvested harvesting sites was observed with the larger site reserve (Figure 11).

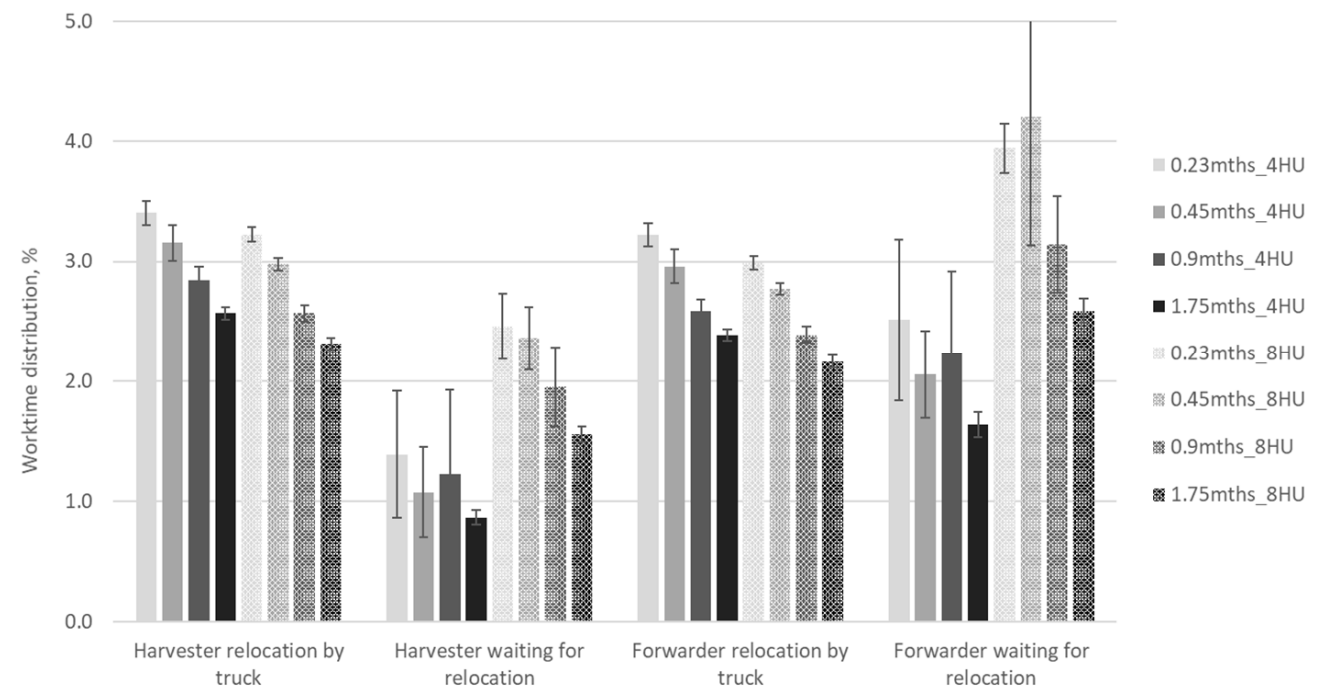

Figure 10. The shares of machine relocation and waiting for the relocation with harvester and forwarder of the total working time when the average harvesting site reserve in months (mths) varied for scenario runs of 4 and 8 HU. Shown are 95\% CI error bars for 7 replications.
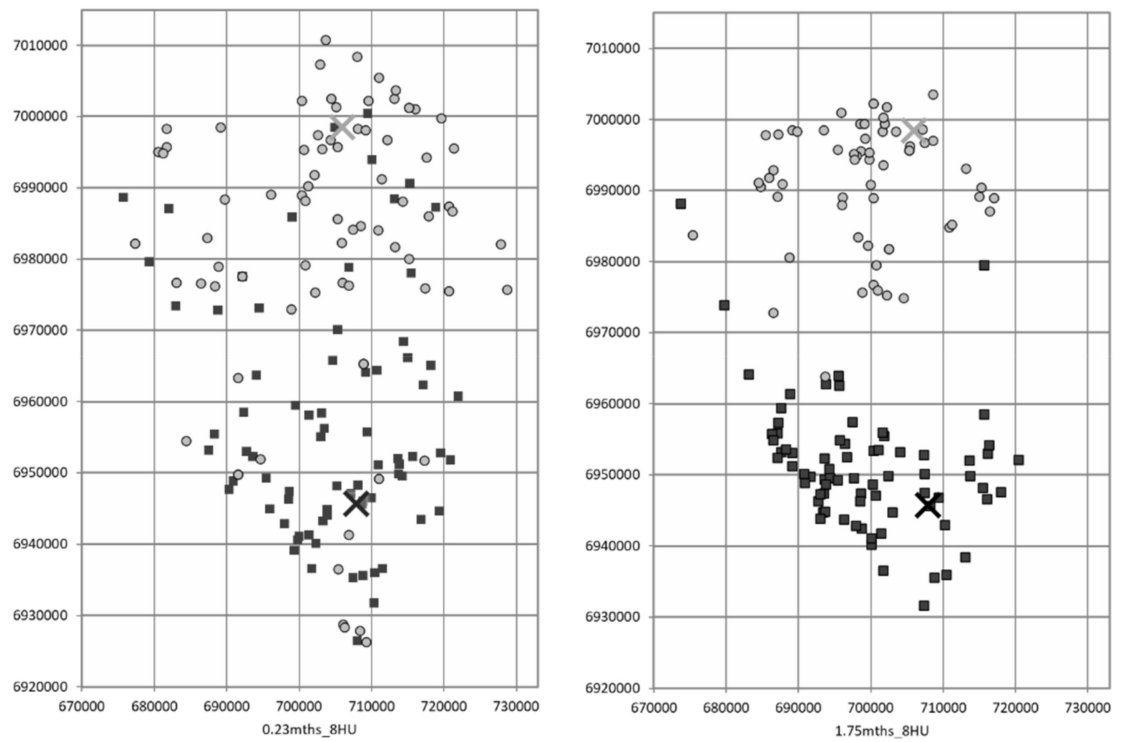

Figure 11. An example of the locations of the harvested sites by two of the eight harvester-forwarder (HU) units for 0.23 and 1.75 months of harvesting site reserves with $8 \mathrm{HU}$. The harvested sites of the seventh replication of two HUs are marked in black boxes ( $1 \mathrm{HU})$ and grey circles $(2 \mathrm{HU})$. The base locations are marked as crosses in respective colors.

The impact of the increase in the site reserve on harvesting costs was logarithmically shaped within the range of site reserves in both simulation scenario sets of 4 and $8 \mathrm{HU}$, i.e., the effect of the site reserve size on harvesting costs was greater in smaller site reserves than larger site reserves. An increase of roughly two weeks from 0.45 months to 0.9 months in site reserve decreased harvesting costs by $1.5 \%$ and $1.2 \%$ in 4 and $8 \mathrm{HU}$ scenarios, respectively (Figure 12). 


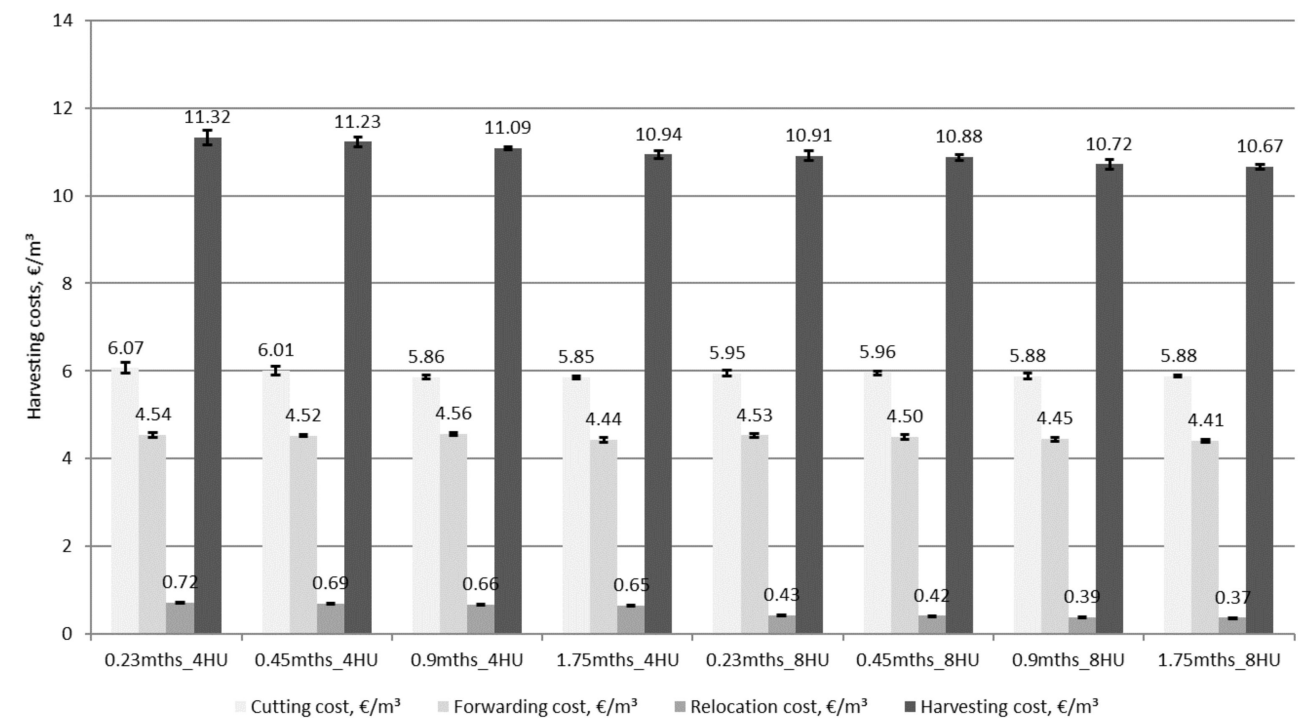

Figure 12. Harvesting costs for scenarios with a varying site reserve for the 4 and $8 \mathrm{HU}$ options. Error bars represent $95 \%$ CI of 7 scenario replications.

\subsection{Timing of Machine Relocations}

In the $4 \mathrm{HU}$ scenario, $12 \mathrm{~h}$ of readiness for relocations per working day $(8 \mathrm{~h}+4 \mathrm{~h}$ stby) were adequate for conducting relocations, with only a slight increase in machines' waiting times for relocations compared to scenarios of $18 \mathrm{~h}$ readiness for relocations per day (Figure 13). On the contrary, the $8 \mathrm{HU}$ scenario of a $12 \mathrm{~h}$ readiness for relocations $(8 \mathrm{~h}+4 \mathrm{~h}$-stby) was insufficient to accomplish relocations without a distinct increase in waiting times for relocation. In $4 \mathrm{HU}$ scenarios with an $18 \mathrm{~h}$ readiness for relocations, only $2.5 \%$ of relocations started after 18:00, and in respective $8 \mathrm{HU}$ scenarios, the share of relocations was $5 \%$ (Figure 14). Compared to the $18 \mathrm{~h}$ scenarios (i.e., $8 \mathrm{~h}+10 \mathrm{~h}$-stby or $18 \mathrm{~h}$-stby), a $12 \mathrm{~h}$ readiness for relocations per day resulted in a significantly larger number of relocations immediately at the start of the work shift.

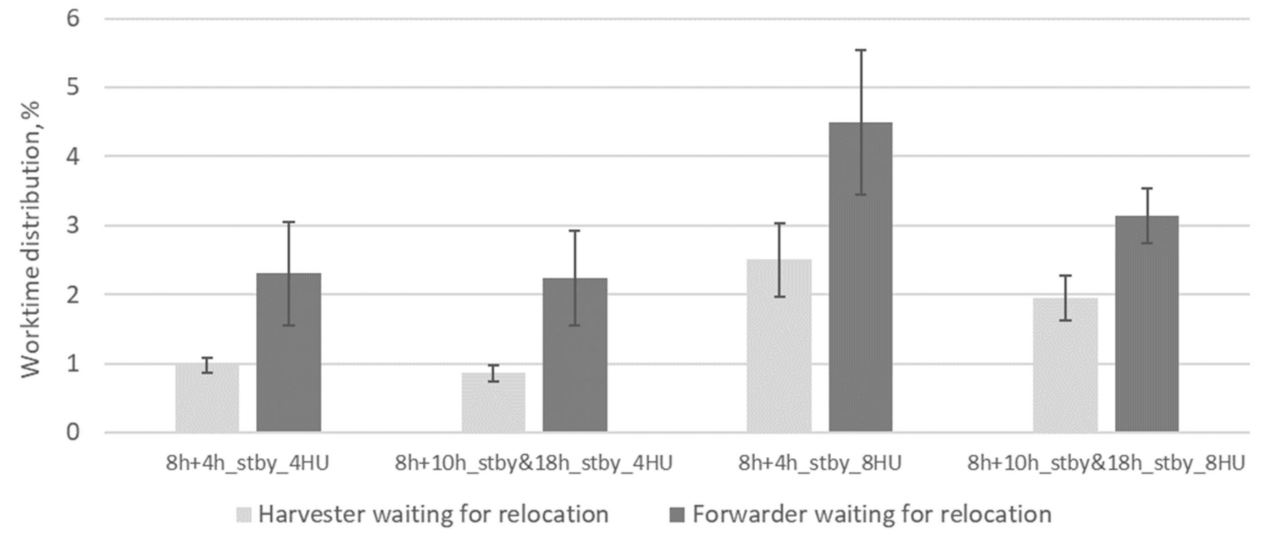

Figure 13. Impact of the relocation options in terms of the readiness time for relocations per working day. The $8 \mathrm{~h}+4 \mathrm{~h}$-stby consisted of an $8 \mathrm{~h}$ work shift of a relocation truck driver added to $4 \mathrm{~h}$ of standby mode managed by the head personnel of the harvesting entrepreneur. The $8 \mathrm{~h}+10 \mathrm{~h}$-stby and $18 \mathrm{~h}$-stby consisted of $18 \mathrm{~h}$ readiness for relocations per day. 


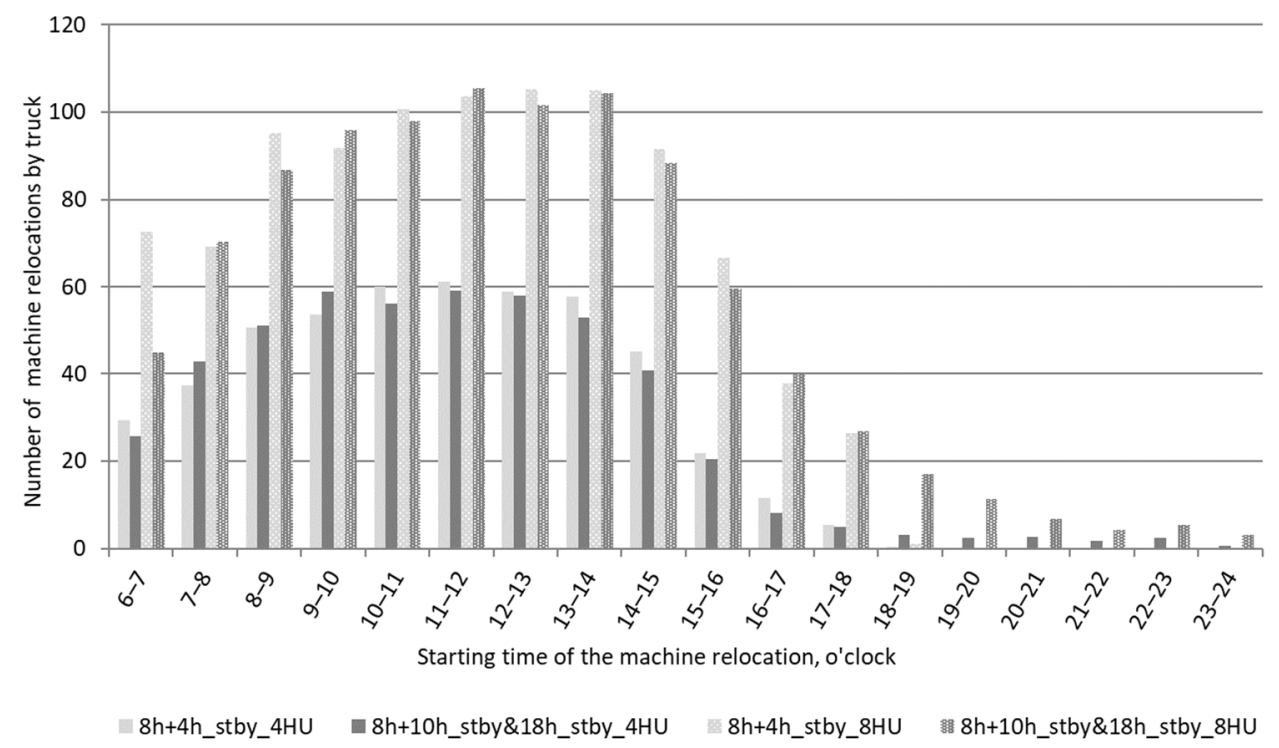

Figure 14. Distribution of starting times of machine relocations in each scenario run. The scenario bars represent averages of 7 replications.

In the $4 \mathrm{HU}$ scenario, employing a relocation truck driver for an $8 \mathrm{~h}$ working shift per day entailed an increase in relocation costs of roughly $93 \%$, and harvesting costs of $3.0 \%$, compared with $8 \mathrm{~h}+10 \mathrm{~h}$-stby and 18h-stby (Figure 15). In contrast, in the $8 \mathrm{HU}$ scenario, the respective values were $72 \%$ and $1.5 \%$. In the $8 \mathrm{HU}$ scenario, an economic benefit could be achieved if machine relocations were carried out with an $18 \mathrm{~h}$ readiness level instead of the $12 \mathrm{~h}$ option. Readiness for the relocations that were six hours longer per day reduced the waiting times of harvesters and forwarders for relocation and increased the share of productive machine time $(\mathrm{PMH})$, and therefore the mean costs in cutting and forwarding decreased by $0.7 \%$ and $2.4 \%$, respectively.

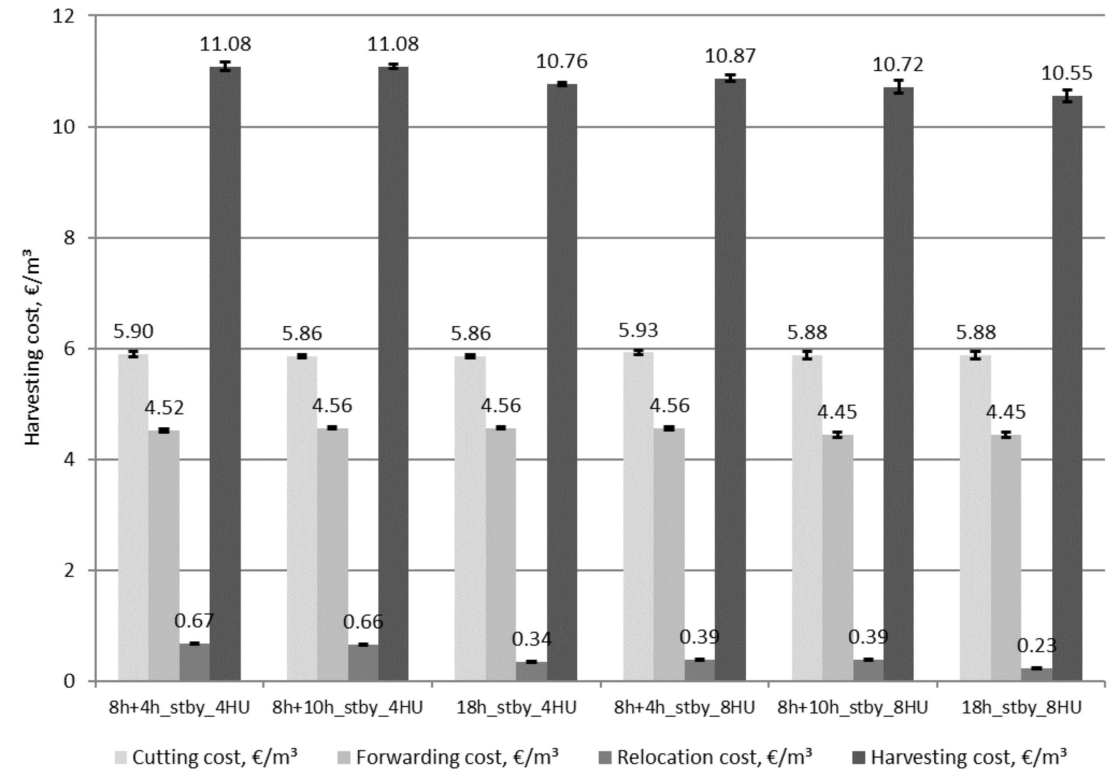

Figure 15. Harvesting costs for the scenarios with alternative relocation options for the 4 and $8 \mathrm{HU}$ fleet sizes. The $8 \mathrm{~h}+4 \mathrm{~h}$-stby consisted of the $8 \mathrm{~h}$ work shift of a relocation truck driver added to a $4 \mathrm{~h}$ standby mode managed by the harvesting entrepreneur's head personnel. The $8 \mathrm{~h}+10 \mathrm{~h}-$ stby and 18h-stby consisted of an $18 \mathrm{~h}$ readiness for relocations. Error bars represent $95 \% \mathrm{CI}$ of 7 scenario replications. 


\section{Discussion}

Unlike earlier system analysis studies of CTL harvesting operations that used the historical data of harvested sites, e.g., $[11,12,18,25]$, a new approach to generating harvesting site data from the National Forest Inventory campaign was achieved in this study. The method for generating harvesting sites considered the expectation of cutting by different regimes within a 10-year period in each inventory plot stand, thus enabling the impact of altered shares of cutting regimes on operations and costs to be foreseen. Spatial open-source data (e.g., static trafficability map and road data by Digiroad) were linked to harvesting sites to assess the accessibility and timing for harvesting, and to determine the distances for the forwarding, driving to work, and machine relocations.

The procedure used, which utilized classification values of the forest trafficability map, was subject to drawbacks in correctly estimating the trafficability of the harvesting site. The procedure used in our study did not consider the terrain trafficability analysis between the central area of the harvesting site and the landing, and the quality and the trafficability of the road from the landing onwards. However, the main goal was to test and utilize the forest trafficability map for the first time in the system analysis simulations of CTL timber harvesting, knowing that the open terrain trafficability information, in addition to the processing and utilizing of the data, are in continuous development, thus resulting in more precise temporal and spatial estimates in the future. In practice in Finland and Sweden, forest trafficability map and the depth-to-water map solutions have been used at a vast scale in the planning of timber harvesting for reducing the harvesting impact on soils for several years [36,37]. Moreover, active development work has been undertaken on weather-driven, dynamic trafficability maps, e.g., [41,42].

A calibration of the harvester's productivity function was carried out in the recent larger harvester follow-up study by Jylhä et al. [40] to update the formulas for today's purposes. The same fused forwarder productivity model was used for regeneration cuttings and thinnings, which resulted in slightly higher values in thinnings compared to the studies of, e.g., $[27,28]$. Productivity functions of forwarders need to be updated for future studies with the use of the system simulator.

In this study, machine utilization rates (MU\%) for the harvesters and forwarders were roughly 4-6\% higher than in the previous studies by Kärhä et al. [11], Eriksson and Lindroos [28], and Jylhä [40]. For harvesters, MU\% ranged between 78 and 81 [28,40], and for forwarders $\mathrm{MU} \%$ was 84 [28]. One reason for the higher $\mathrm{MU} \%$ of machines was the location of the operating area in Eastern Finland, which has larger forest properties than in Southern and Western Finland, enabling larger cutting sites to be defined for harvesting. This study's average site removal was $588 \mathrm{~m}^{3}$, whereas in the studies of Väätäinen et al. [12,24,25], with cutting areas concentrated in Southern and Western Finland, the harvesting site removals of case contractors averaged $440 \mathrm{~m}^{3}$, ranging between 270 and $535 \mathrm{~m}^{3}$, and depending greatly on the geographical location of sites. Larger cutting site units reduce the total share of time used for the setups at the start of the new harvesting sites, the total time for the machine relocations, and the waiting time for the relocations, thereby having a positive effect on the $\mathrm{MU} \%$ of harvesting machines.

In comparing the study result with practice, it is worth highlighting some differences between the simulation model and practice. All the machines were paused when the rest period was activated, whereas in practice, some machine operators and machines are in laydown while the other labor and machine resources are in use. According to the statistics for the last five-year period in Finland [43], one-third of the machine capacity is in use during the thaw and summer. Typically, during the low season, some forwarding capacity is utilized for extracting harvesting residues for energy from spruce-dominated final fellings. Furthermore, the demand for sawnwood assortments varies throughout the year due to storage volume levels, the thaw and holiday seasons, and sudden changes in sawnwood markets [44]. Operating on Saturdays and a two-shift work mode are more typical during the winter; during the summer and spring, a one-shift mode is more common. Furthermore, all machines were defined as being similar in size and equipment, enabling them to be 
operated on all sites and cutting types. However, in practice, larger entrepreneurs, in particular, have machines of varying sizes and equipment, adding another feature to machine productivity, site selection, and machine allocation. In terms of size classes, allpurpose machines are the most used, both for harvesters and forwarders, in northern countries [45].

Additional machine relocations other than those modeled in the simulations occur in practice for maintenance, repair, and parking for lay-downs, in addition to extra relocations to/from sites with insufficient ground-bearing capacity or preclearing of undergrowth on harvesting sites. By comparison, the CALL table was strict in carrying out relocations according to order, even though in some cases it would have been more feasible for the next machine (M2) to appear promptly in the waiting line of the CALL table before the machine (M1) standing earlier in the waiting line and located much farther from the truck than the M2 machine. In this respect, smarter decisions in ordering and routing machine relocations are made in practice. Overall, average machine relocation distances, and trip time durations and distances, were consistent with those in the studies of, e.g., Kärhä et al. [8] and Kauppinen [10].

As seen in this study, most harvesting entrepreneurs in Finland tend to carry out machine relocation with their own trucks, e.g., [4]. However, relocation services are utilized when an urgent need arises, especially when the entrepreneur's own truck is occupied for a longer time or is free but located far away. Networking between machine entrepreneurs and buying relocation services are included in business portfolios to improve operating efficiency $[4,7,10]$.

Many productivity and time consumption functions of mechanized CTL harvesting have typically described the response variable in the function of some stand and machine parameters, without taking the operator effect into account. The operator's effect on machine performance is noticeable $[29,46,47]$, and productivity within operators may vary greatly, even in the same harvesting conditions, due to the operator's motivation and experience, the working technique they use, their sensory motor abilities (i.e., crane and generator control), skill level, mental workload, and workability and wellbeing, e.g., [46-50]. Moreover, temporal and spatial changes in the operating environment constantly affect the performance of the human-machine system, thereby increasing performance variation in the system. In terms of the size of the business, larger entrepreneurs tend to have better opportunities to recruit more skilled machine operators, the site reserves are bigger, the machinery is newer, and the annual machine production is higher [4]. However, by outlining some of the features, variables, and external factors influencing the operational system, in addition to equalizing some parameter values for all scenarios, it is possible to examine the objectives of this study with improved control and better accuracy. Thus, the magnitude of scenario differences and the order of scenarios, i.e., the trend, can be more reliably detected.

In all size scenarios, by enlarging the scale of the operation via increasing the size of the fleet, economies of scale were distinguishable, which supported the findings of Väätäinen et al. [12] and Kauppinen [10]. In this study, in low-bed truck utilization scenarios, the relocation cost per harvested $\mathrm{m}^{3}$ of timber was reduced by half, and harvesting costs by roughly $8 \%$, if the size of the fleet was doubled from 2 to $4 \mathrm{HU}$. Second, a larger fleet with a bigger site reserve made more sites available for selection where machines were relocated. In turn, this shortened relocation distances and reduced the time forest machines were involved in machine relocations. However, machine waiting before the relocation was found to increase when the fleet size increased. Doubling the site reserve removal reduced harvesting costs by $0.5-1.5 \%$, depending on the compared scenarios. Furthermore, administration and maintenance costs, in addition to work driving expenses per machine, decreased when the fleet size increased. Jylhä et al. [4] found that larger harvesting companies typically had bigger site reserves than smaller ones.

In terms of cost-effective relocation options, the study's results justify the corresponding findings from practice $[10,12]$; the use of a relocation truck by smaller entrepreneurs 
( 2 to $4 \mathrm{HU}$ ) remains at a level at which it is not economically feasible to employ a separate driver for the truck. With 6 and 8 HU fleets, average daily operating times were 5.8 and $7.3 \mathrm{~h}$, respectively, for the machine relocations with a low-bed truck, greatly supporting the employment of a separate driver for a one-day shift, and the execution of the small number of occasionally occurring relocations during the remainder of the day with the entrepreneur's own personnel, or the execution of relocations at the beginning of the next working day (see scenarios in Figure 14). This is in line with the findings in Jylhä et al. [4], where half of the harvesting entrepreneurs with an annual turnover of more than EUR 2 million recruited staff for machine relocations and other supporting tasks. According to the scenario results, the annual turnover in the 6 and $8 \mathrm{HU}$ scenarios was roughly EUR 2.4 and 3.2 million, respectively. It should be noted that all the scenarios were carried out with a setup using one relocation truck owned by the entrepreneur.

At present, novel simulation software applications and other operation research (OR) tools are highly applicable for a more precise system analysis of supply chains and logistics, with the enhanced availability of a vast amount of input data from several sources [51]. The developed system analysis model for Nordic CTL harvesting is a feasible tool to support the strategic planning of wood harvesting operations, while comparing and analyzing cost-effective and resource-efficient options for, e.g., executing machine relocations, and structuring and sizing the harvesting fleet. In future, as a result of further development of the system analysis model, significant interest will be generated for evaluation of the impact of the weather (e.g., climate change), the trafficability variation of the forests and the road network, the changes in timber demand, or the changes of cutting regimes on harvesting performance indicators, including $\mathrm{CO}_{2}$ emissions. The modeling of temporal and spatial changes may further improve model performance and reliability.

\section{Conclusions}

This study highlighted the economies of scale and the phenomena associated with the interactions between the relocation truck and the harvesting machines (i.e., the harvester and the forwarder) with different fleet sizes in mechanized CTL harvesting in Eastern Finland. The utilization level of the relocation truck had a significant influence on the harvesting costs. Bigger fleet size supported more the use of an owned relocation truck with a designated driver for the truck. The increased utilization of the truck lowers the relocation costs per harvested cubic meter of timber $\left(\mathrm{EUR} / \mathrm{m}^{3}\right)$. In turn, however, the truck was more often occupied and the need for new machine relocation increased, and thus, the waiting time of machines was increased. Moreover, with the bigger fleet size, the number of harvesting sites per fleet increased, resulting in more sites available for the site selection. Therefore, machine relocation distances and times were decreased. The study results emphasize the importance of entrepreneur-specific strategic and operational planning of machine relocations in cost-efficient CTL harvesting.

Author Contributions: Planning, conceptual system scheme for the timber harvesting model, and the selection of simulation scenarios were carried out by K.V., J.L. and V.K. Data extraction from NFI, MELA calculations, and ArcGIS analyses were performed by P.H. and H.H. K.V. was responsible for modeling, simulations, the analysis of the simulation results, and writing the original draft. V.K. was responsible for project planning, funding acquisition, and the supervision of the DigiELMO project. All authors have read and agreed to the published version of the manuscript.

Funding: Data collection: the modeling of the system analysis simulation model, and simulations were funded through the DigiELMO (new business from forest digitalization) project, which was funded by the European Regional Development Fund for the Regional Council of North Karelia. The analysis of simulations and the publication of the results were funded through the OpenForData, AgileSilviTech (Agile silvicultural technology solutions for bio-based industry), and Forbio projects (3500010200). 
Acknowledgments: The authors thank Janne Tahvanainen from Karelwood Oy, Timo Toropainen from Toropainen Oy, and Jussi Puoskari from Motoajo Oy for giving valuable comments related to operations, costing, and business in wood harvesting, which helped to structure and develop a system analysis model that was closer to practice. We are grateful for Tuula Packalen for the valuable mentoring, encouragement, and comments on our work.

Conflicts of Interest: The authors declare no conflict of interest. The funders had no role in the design of the study; in the collection, analyses, or interpretation of data; in the writing of the manuscript; or in the decision to publish the results.

\section{References}

1. Strandström, M. 2019. Puunkorjuu ja kaukokuljetus vuonna 2018. Metsätehon tuloskalvosarja 17a/2019. 32 Slides. Available online: https://www.metsateho.fi/wp-content/uploads/Tuloskalvosarja_2019_17a_Puunkorjuu_ja_kaukokuljetus_vuonna_ 2018.pdf (accessed on 21 May 2021).

2. Commercial Fellings. Natural Resources Institute Finland. Available online: https://stat.luke.fi/en/commercial-roundwoodremovals-and-forestry-labour (accessed on 21 May 2021).

3. Statistics Database. Natural Resources Institute Finland. Available online: https://statdb.luke.fi/PXWeb/pxweb/en/LUKE/ ?rxid=9ad16a36-53a5-4fa7-aaf8-ffe27fa6a858 (accessed on 21 May 2021).

4. Jylhä, P.; Rikkonen, P.; Hamunen, K. Size matters-An analysis of business models and the financial performance of Finnish wood-harvesting companies. Silva Fenn. 2020, 54, 10392. [CrossRef]

5. Soirinsuo, J. Growth and Profitability of Logging and Transportation in Wood Procurement Companies in Finland: What Strategies and Entrepreneurs Are Needed for Profitable Growth? Ph.D. Thesis, University of Helsinki, Department of Economics and Management, Helsinki, Finland, 2012. Publication No. 54. 90p. Available online: http:/ / urn.fi/URN:ISBN:978-952-10-8386-0 (accessed on 13 May 2021).

6. Kuitto, P.J.; Keskinen, S.; Lindroos, J.; Oijala, T.; Rajamäki, J.; Räsänen, T.; Terävä, J. Puutavaran Koneellinen Hakkuu ja Metsäkuljetus; 1994. Tiedotus; Metsäteho Report 410; 38p. Available online: https://metsateho.fi/wp-content/uploads/tiedotus-1994_410.pdf (accessed on 20 May 2021).

7. Väätäinen, K.; Asikainen, A.; Sikanen, L.; Ala-Fossi, A. The cost effect of forest machine relocations on logging costs in Finland. For. Stud. I Metsanduslikud Uurim. 2006, 45, 135-141.

8. Kärhä, K.; Poikela, A.; Rieppo, K.; Imponen, V.; Keskinen, S.; Vartiamäki, T. Korjurit Ainespuun Korjuussa; 2007. Metsätehon Raportti 200,50p. Available online: https://metsateho.fi/wp-content/uploads/2015/02/metsatehon_raportti_200.pdf (accessed on 15 May 2021).

9. Friman, J.-M. Metsäkoneiden Siirtojen Toteutustavat ja Kustannukset-Otos Keski-Suomen ja Savon Korjuuyrittäjistä. Bachelor's Degree, Joensuun Yliopisto, Metsätieteellinen Tiedekunta, Joensuu, Finland, 2009; 24p.

10. Kauppinen, J. Puunkorjuuyritysten Konesiirtojen Toteutustavat, Kustannukset ja Ajanmenekit—Otos Pohjois-Savon Puunkorjuuyrityksistä. (Logging Companies Harvester Relocation Costs and Down Time Caused by Relocations). Bachelor's Degree, Pohjois-Karjalan Ammattikorkeakoulu, Joensuu, Finland, 2010; 71p.

11. Kärhä, K.; Poikela, A.; Palander, T. Productivity and Costs of Harwarder Systems in Industrial Roundwood Thinnings. Croat. J. For. Eng. 2018, 39, 23-33.

12. Väätäinen, K.; Lappalainen, M.; Asikainen, A.; Anttila, P. Kohti Kustannustehokkaampaa Puunkorjuuta—Puunkorjuuyrittäjän Uusien Toimintamallien Simulointi; 2008. Metla Working Papers 73. 52p. Available online: http://www.metla.fi/julkaisut/workingpapers/ 2008/mwp073.htm (accessed on 14 August 2021).

13. Hultåker, O. Entreprenörskap i Skogsdrivningsbranschen. En Kvalitativ Studie om Utveckling i små Företag. Ph.D. Thesis, Swedish University of Agricultural Sciences, Uppsala, Sweden, 2006; 202p.

14. Soirinsuo, J.; Mäkinen, P. Importance of the financial situation for the growth of a forest machine entrepreneur. Scand. J. For. Res. 2009, 24, 264-272. [CrossRef]

15. Penttinen, M.; Rummukainen, A.; Mikkola, J. Profitability, liquidity and solvency of wood harvesting contractors in Finland. Small Scale For. 2011, 10, 211-229. [CrossRef]

16. Manner, V.; Järvinen, V. Metsäkoneyritysten Tulostaso Oli Kehno Vuonna 2012. TTS:n Tiedote. Metsätyö, -Energia ja Yrittäjyys 5/2013 (766); Työtehoseura: Rajamäki, Finland, 2013; 4p. (In Finnish)

17. Kronholm, T.; Sosa, A.; Bowditch, E.; Pohlschneider, S.; Hamunen, K.; Rikkonen, P. State of the Art and Development Needs of Forestry Service Contractors in the Northern Periphery and Arctic Region; Project report, 2019; 53p. Available online: https:/ / www.luke.fi/fobia/wp-content/uploads/sites/21/2019/11/State-of-the-art-and-development-needs-of-forestryservice-enterprises-in-the-NPA-region.pdf (accessed on 3 December 2019).

18. Nurminen, T.; Korpunen, H.; Uusitalo, J. Applying the activity-based costing to cut-tolength timber harvesting and trucking. Silva Fenn. 2009, 43, 847-870. [CrossRef]

19. Williams, C.; Ackerman, P. Cost-productivity analysis of South African pine sawtimber mechanised cut-to-length harvesting. South. For. J. For. Sci. 2016, 78, 267-274. [CrossRef] 
20. Asikainen, A. Discrete-Event Simulation of Mechanized Wood-Harvesting Systems; Research Notes 38; University of Joensuu, Faculty of Forestry: Joensuu, Finland, 1995; 86p.

21. Oinas, S.; Sikanen, L. Discrete event simulation model for purchasing of marked stands, timber harvesting and transportation. For. Int. J. For. Res. 2000, 73, 283-301. [CrossRef]

22. Asikainen, A. Simulation of Logging and Barge Transport of Wood from Forests on Islands. Int. J. For. Eng. 2001, 12, 43-50. [CrossRef]

23. Talbot, B.; Nordfjell, T.; Suadicani, K. Assessing the Utility of Two Integrated Harvester-Forwarder Machine Concepts Through Stand-Level Simulation. Int. J. For. Eng. 2003, 14, 31-43. [CrossRef]

24. Väätäinen, K.; Liiri, H.; Röser, D. Cost competitiveness of harwarders in CTL-logging conditions in Finland-A discrete-event simulation study at the contractor level. In Precision Forestry in Plantations, Semi-Natural and Natural Forests, Proceedings of the International Precision Forestry Symposium, Stellenbosch University, South Africa, 5-10 March 2006; Ackerman, P., Längin, D., Antonides, M., Eds.; Econo Print: Stellenbosch, South Africa, 2006; pp. 451-463.

25. Väätäinen, K.; Lamminen, S.; Sirén, M.; Ala-Ilomäki, J.; Asikainen, A. Ympärivuotisen Puunkorjuun Kustannusvaikutukset Ojitetuilla Turvemailla-Korjuuyrittäjätason Simulointitutkimus. 2010. Metlan Työraportteja/Working Papers of the Finnish Forest Research Institute 184. 57p. Available online: http://www.metla.fi/julkaisut/workingpapers/2010/mwp184.htm (accessed on 20 June 2021).

26. She, J.; Chung, W.; Kim, D. Discrete-Event Simulation of Ground-Based Timber Harvesting Operations. Forests 2018, 9, 683. [CrossRef]

27. Nurminen, T.; Korpunen, H.; Uusitalo, J. Time consumption analysis of the mechanized cut-to-length harvesting system. Silva Fenn. 2006, 40, 335-363. [CrossRef]

28. Eriksson, M.; Lindroos, O. Productivity of harvesters and forwarders in CTL operations in northern Sweden based on large follow-up datasets. Int. J. For. Eng. 2014, 25, 179-200. [CrossRef]

29. Liski, E.; Jounela, P.; Korpunen, H.; Sosa, A.; Lindroos, O.; Jylhä, P. Modeling the productivity of mechanized CTL harvesting with statistical machine learning methods. Int. J. For. Eng. 2020, 31, 253-262. [CrossRef]

30. Asikainen, A. Simulation of stump crushing and truck transport of chips. Scand. J. For. Res. 2010, 25, 245-250. [CrossRef]

31. Lanner. Available online: https://www.lanner.com/en-us/technology/witness-simulation-software.html (accessed on 12 June 2021).

32. Valtakunnan Metsien 12. Inventointi (VMI12). Maastotyön Ohjeet; Luonnonvarakeskus: Helsinki, Finland, 2017; 164p.

33. Hirvelä, H.; Härkönen, K.; Lempinen, R.; Salminen, O. MELA2016—Reference Manual 2016; Natural Resources and Bioeconomy Studies 7/2017. 547p. Available online: https:/ /jukuri.luke.fi/handle/10024/538149 (accessed on 15 June 2021).

34. Siitonen, M.; Härkönen, K.; Hirvelä, H.; Jämsä, J.; Kilpeläinen, H.; Salminen, O.; Teuri, M. MELA Handbook 1996 Edition 1996. The Finnish Forest Research Institute, Research Papers 622. 452p. Available online: http:/ / urn.fi/URN:ISBN:951-40-1543-6 (accessed on 16 June 2021).

35. MELA Summary Reports. Natural Resources Institute Finland. Available online: https://www.luke.fi/mela-cutting-possibilities/ (accessed on 16 June 2021).

36. Bergqvist, I.; Willén, E.; Väätäinen, K.; Lindeman, H.; Uusitalo, J.; Lauren, A.; Peuhkurinen, J. Big Data Bases and Applications. Planning for Precision Forestry by Means of Trafficability Maps. 2017. 13p. Available online: https://www.luke.fi/efforte/wp-content/ uploads / sites/14/2017/09/EFFORTE-D3.4-Planning-for-precision-forestry-by-means-of-trafficability-maps.pdf (accessed on 16 June 2021).

37. Kankare, V.; Luoma, V.; Saarinen, N.; Peuhkurinen, J.; Holopainen, M.; Vastaranta, M. Assessing feasibility of the forest trafficability map for avoiding rutting-A case study. Silva Fenn. 2019, 53, 10197. [CrossRef]

38. Digiroad. Digiroad-National Road and Street Database. Available online: https://www.liikennevirasto.fi/web/en/open-data/ digiroad\#.W-Ey69UzZEY (accessed on 20 May 2021).

39. Björheden, R.; Apel, K.; Shiba, M.; Thompson, M.A. IUFRO Forest Work Study Nomenclature; Swedish University of Agricultural Science, Dept. of Operational Efficiency: Garpenberg, Sweden, 1995; 16p.

40. Jylhä, P.; Jounela, P.; Korpunen, H.; Koistinen, M. Koneellinen Hakkuu. Seurantatutkimus. [Mechanised Cutting. Follow-up Study]; Luonnovara-ja biotalouden tutkimus 11/2019; Luonnonvarakeskus (Luke): Helsinki, Finland, 2019; 53p, Available online: http:/ / urn.fi/URN:ISBN:978-952-326-717-6 (accessed on 16 June 2021).

41. Salmivaara, A.; Launiainen, S.; Perttunen, J.; Nevalainen, P.; Pohjankukka, J.; Ala-Ilomäki, J.; Sirén, M.; Laurén, A.; Tuominen, S.; Uusitalo, J.; et al. Towards dynamic forest trafficability prediction using open spatial data, hydrological modelling and sensor technology. For. Int. J. For. Res. 2020, 93, 662-674. [CrossRef]

42. Venäläinen, A.; Luhtala, S.; Laapas, M.; Hyvärinen, O.; Gregow, H.; Strahlendorff, M.; Peltoniemi, M.; Suvanto, S.; Nevalainen, S.; Peltola, H.; et al. Sää-ja Ilmastotiedot sekä Uudet Palvelut Auttavat Metsäbiotaloutta Sopeutumaan Ilmastonmuutokseen; Raportteja 2021:1; Ilmatieteen Laitos: Helsinki, Finland, 2021; 52p, Available online: http:/ /hdl.handle.net/10138/324894 (accessed on 12 August 2021).

43. Commercial Fellings, Monthly Statistics. Natural Resources Institute Finland. Available online: https://statdb.luke.fi/PXWeb/ pxweb/en/LUKE/ (accessed on 16 August 2021). 
44. Ylioja, T.; Ahtikoski, A.; Anttila, P.; Haikarainen, S.; Honkaniemi, J.; Laitila, J.; Melin, M.; Tuula, P.; Väätäinen, K. Metsätuholain Arvioinnin Jatkoselvitys: Kuorellisen Puutavaran Poiskuljetus ja Männiköiden Kantokäsittely Turvemailla. 2021. 20/2021. 77p. Available online: http:/ / urn.fi/URN:ISBN:978-952-380-183-7 (accessed on 13 June 2021).

45. Malinen, J.; Laitila, J.; Väätäinen, K.; Viitamäki, K. Variation in age, annual usage and resale price of cut-to-length machinery in different regions of Europe. Int. J. For. Eng. 2016, 27, 95-102. [CrossRef]

46. Ovaskainen, H. Timber Harvester Operators' Working Technique in First Thinning and the Importance of Cognitive Abilities on Work Productivity. Ph.D. Thesis, University of Joensuu, Joensuu, Finland, 2009.

47. Purfürst, F.T.; Erler, J. The Human Influence on Productivity in Harvester Operations. Int. J. For. Eng. 2011, 22, 15-22. [CrossRef]

48. Väätäinen, K.; Ovaskainen, H.; Ranta, T.; Ala-Fossi, A. Hakkuukoneenkuljettajan Hiljaisen Tiedon Merkitys Työtulokseen Työpistetasolla. [The Effect of Harvester Operator's Tacit Knowledge on Work Result at the Level of Processing Location]; Metsäntutkimuslaitoksen Tiedonantoja 937: Metla; Joensuun Tutkimuskeskus: Joensuu, Finland, 2005; 100p.

49. Spinelli, R.; Natascha, M.; Labelle, E.R. The Effect of New Silvicultural Trends on Mental Workload of Harvester Operators. Croat. J. For. Eng. 2020, 41, 177-190. [CrossRef]

50. Kymäläinen, H.; Laitila, J.; Väätäinen, K.; Malinen, J. Workability and Well-Being at Work among Cut-To-Length Forest Machine Operators. Croat. J. For. Eng. 2021, 42, 405-417. [CrossRef]

51. Kankaanhuhta, V.; Packalen, T.; Väätäinen, K. Digital Transformation of Forest Services in Finland-A Case Study for Improving Business Processes. Forests 2021, 12, 781. [CrossRef] 